\title{
Teologie as werklikheidsverstaan - anders dink, anders doen: Aantekeninge oor die teologie van Johan Buitendag
}

\section{Authors: \\ Andries G. van Aarde \\ Tanya van Wyk $^{2}$ \\ Affiliations: \\ Department of New \\ Testament Studies, Faculty of Theology, University of \\ Pretoria, South Africa \\ ${ }^{2}$ Department of Dogmatics and Christian Ethics, Faculty of Theology, University of Pretoria, South Africa \\ Note: \\ Article republished with a correction under the heading 'Erkenning' on page 13 of 14. \\ Correspondence to: \\ Andries van Aarde \\ Email: \\ andries.vanaarde@up.ac.za}

\section{Postal address:}

Private Bag X20, Hatfield

0028, South Africa

Dates:

Received: 16 Sept. 2014

Accepted: 29 Oct. 2014

Published: 20 Nov. 2014

Republished: 27 Nov. 2014

How to cite this article: Van Aarde, A.G. \& Van Wyk, T., 2014, 'Teologie as werklikheidsverstaan - anders dink, anders doen: Aantekeninge oor die teologie van Johan Buitendag', HTS Teologiese Studies/Theological Studies 70(1), Art. \#2823, 14 pages. http://dx.doi.org/10.4102/ hts.v70i1.2823

\section{Copyright:}

C) 2014. The Authors. Licensee: AOSIS OpenJournals. This work is licensed under the Creative Commons Attribution License.

Read online:
Theology as understanding reality - thinking differently, acting differently: Notes about the theology of Johan Buitendag. The article investigates the theological contours delineated from the publications of the systematic theologian Johan Buitendag. His theology represents a relational integrity of ontology, epistemology and ethics. It can be characterised as an existential ecotheology. In the introduction this rhizome (epistemological metaphor borrowed from Giles Deleuze and Félix Guattari) existence in Buitendag's theology is discussed. The article consists of nine sections: the hermeneutical circle as introduction; the polemic attitude of Karl Barth with regard to a theologia naturalis; understanding the notion paradigm; being church as a relational event; engaged epistemology; existential theo-anthropology and ecotheology; existential ecclesiology; existential engagement; and an autobiographical reflection.

\section{Hermeneutiese sirkel}

Verstaan is ' $n$ proses wat as 'n sirkel voorgestel kan word en daarom word die uitdrukking 'hermeneutiese sirkel' gebruik. In hierdie sirkulariteit kan kommunikasie - en daarom die hermeneutiese proses - op enige tydstip opgeskort word en dan kom verstaan tot 'n einde. Martin Heidegger ([1962] 2008:195) se waarneming is dus korrek dat dit nie 'n vraag is hoe om uit die sirkel uit te kom nie, want kommunikasie kan enige tyd beëindig word. Die vraag is eerder hoe om op die korrekte wyse in die sirkel in te kom - dit wil sê hoe om in konkrete ervaring te verstaan en te kommunikeer. Interpretasie vind nie plaas deur buite die sirkel van die verstaansproses objektief 'van buite' die werklikheid waar te neem nie, maar inteendeel om midde-in die sirkel in te beweeg en die werklikheid persoonlik te ontmoet en te ervaar (vgl. Thielen 1999:126). Dit kan vergelyk word met 'n skilder wat besig is om iets van die werklikheid op doek vas te lê of die digter wat iets van die lewe in poësie verwoord. Werklikheidsverstaan kan daarom beskou word as 'ein Werk der persönlichen Kunst' (Schloßberger 2005:107). Hiermee word nie 'n soort monoloog bedoel nie (Grondin [1991] 1994:97), maar 'n relasionele dimensie wat kompleks van aard is.

Johan Buitendag se teologie weerspieël insig in hierdie kompleksiteit en die diep persoonlike aard van verstaan en eksistensie. Sy denke moet egter gesien word as 'n verstaansproses wat 'n epistemologie én ontologie én etiek integreer wat nie adekwaat met die begrip hermeneutiese sirkel uitgedruk kan word nie. Dit verteenwoordig nie bloot ' $n$ sirkulêre wisselwerking tussen 'n subjek wat 'n objek waarneem en waar die subjek in die proses van waarneming deur die objek beïnvloed word nie. Buitendag se werklikheidsverstaan is 'eko-kultureel' van aard en die hermeneutiese sirkel is vir hom $360^{\circ}$.

In plaas van om in statiese terme te dink deur te meen dat Buitendag 'n wêreldbeeld of 'n bepaalde teologie sou huldig, is sy teologiese posisie nie antiteties of sinteties nie, maar diastaties. Buitendag is 'n dinamiese Christen-gelowige wat in konstante dialoog met natuurwetenskap die werklikheid probeer verstaan. Soos Alister McGrath (2001:xvii) is hy gemaklik daarmee om as 'n 'scientific theologian' bekend te staan. McGrath (2001:25-26) het daarop gewys dat Nederlands (ook Afrikaans) en Duits nie die term 'wetenskap' (science) vir natuurwetenskap reserveer nie, maar ook op geesteswetenskap (ingesluit teologie) van toepassing is.

Johan Buitendag se 'wetenskaplike teologie' (scientific theology) is beskryfbaar met die soort diskoers wat Giles Deleuze en Félix Guattari ([1980] 1987) met die botaniese terme 'rhizome' en 'rhizomatic' beskryf. Anders as byvoorbeeld bome met wortels wat metafories na 'n epistemologie verwys waar waarneming bestaan uit die deduksie of reduksie van data gebaseer op 'n vaste entiteit (foundation), verwys 'risoom' na ('n) plant(e) in 'n savannehabitat waar die (ondergrondse) worteltakke in multivorme en selfs multispesies verder kan vertak - nie in 'n enkelvormige statiese entiteit nie, maar die wortel (risoom) vertak metamorfies in 'n veelheid van dimensies 
wat alles interafhanklik is. Inherent tot dié soort habitat is daar 'n ruimte wat die ontwikkeling (emergent space) van veelheid moontlik maak (potensialiteite eerder as realiteite). Hermeneuties gesien, indien die begrip 'sirkulariteit' gebruik word, verteenwoordig ' $n$ risoom 'n semiotiese beweging van asignifying na signyfying en weer van signifying na asignyfying. Deleuze en Guattari ([1980] 1987) verduidelik hierdie metafoor in epistemologiese en ontologiese terme soos volg:

Unlike the graphic arts, drawing or photography, unlike tracings, the rhizome pertains to a map that must be produced, constructed, a map that is always detatchable, reversable, modifiable, and has multiple entranceways and exits and its own lines of flight. (bl. 21)

Hierdie artikel het as doel om die integrale relasie van ontologie, epistemologie en etiek in Johan Buitendag se teologiese denke aan te dui. 'n Kritiese aansluiting by eminente kontemporêre sistematiese teoloë is deurgaans in sy oevre aanwesig. Dit is daar sedert sy doktorale proefskrif 'Skepping en ekologie: 'n Sistematiese ondersoek na die teologiese verstaan van die werklikheid' (Buitendag 1985), wat hoofsaaklik by die Universiteit van Erlangen-Nürnberg onder leiding van Friedrich Mildenberger geskryf is. Hierdie teoloë is onder andere Karl Heim, Friedrich Gogarten, Karl Barth, Jürgen Moltmann en Günter Altner. Die teologiese diepgang van sy doktorale studie verdien spesifieke vermelding. In die artikel word Buitendag se analise van veral Barth, Heim en Altner uitgelig - veral sy kritiek op Karl Barth word bespreek om daardeur Buitendag se post-eksistensiële eko-teologie te beklemtoon. Baie meer behoort oor Buitendag se kritiese evaluasie van bogenoemde en ander sistematiese teoloë gesê te word. Ruimte ontbreek egter. Sekere werke kan ten opsigte van sy sentrale interesse, te wete die dialoog tussen teologie en natuurwetenskap, as periferies beskou word. Dit is publikasies wat as ad hoc-studies beskryf kan word omdat dit op uitnodiging vir spesifieke geleenthede soos predikantevergaderings en kerklike adviese geskryf is. Ter wille van volledigheid word daar in hierdie artikel kortliks ook na hierdie werke verwys. Dit sluit temas in soos paradigmateorie en die kindernagmaal. Hierdie periferiese werke demonstreer Buitendag se konsistensie in terme van sy eko-teologie, maar ook hoe hy sy eko-teologie met nuwe insigte verdiep het. Dit is onder andere te sien in die wyse hoe die eksistensiële relasie van Ich en $D u$ in die denke van Martin Buber ontwikkel het in 'n post-eksistensiale eko-kulturele teologiese etiek, wat deur Buitendag met sy verstaan van enersyds panenteïsme en andersyds die verhouding tyd ewigheid as eksistensiële diesseitige dimensie onderbou word.

Sy verinnerlikte hermeneutiek van suspisie het deurgaans in 'ekklesiale kritiek' uitgemond. Hy het ook nie onkrities gestaan teenoor die denominasie waarvan hy predikant is nie, naamlik die Nederduitsch Hervormde Kerk van Afrika. Die tydperk toe hy as moderator van dié kerkgenootskap gedien het, het daartoe gelei dat die demistifikasie van die rassistiese ideologiese onderbou van die Hervormde Kerk 'n hoogtepunt bereik het.

Die tydperk daarna is oorheers deur sy dekaanskap van die Fakulteit Teologie van die Universiteit van Pretoria. In hierdie tyd vertak die 'teologiese' risoom in dimensies wat die verhouding teologie en onderwys in post-apartheid SuidAfrika as tema tot sy eko-teologie toevoeg. Die betekenisvolle insigte van hierdie dimensie in die loopbaan van Buitendag as veelsydige teoloog is veral te sien in die 'fakulteitsplanne' wat jaarliks aan die universitêre hoofbestuur voorgelê moes word (en vir die argiewe beskikbaar gestel sal word). In hierdie artikel word ook hierdie dimensie as gevolg van ruimtebeperking nie bespreek nie.

Die artikel word afgesluit met 'n persoonlike blik van Buitendag self op sy teologie. Voordat Buitendag self aan die einde van die artikel aan die woord kom, word daar in die voorafgaande refleksie op sy teologiese diskoers tot op hede teruggekeer na 'verstaan' as eksistensiële lewe. Hierdie 'eksistensiële betrokkenheid' word aangebied as 'n ontmoeting met die werklikheid, geïnterpreteer as 'n persoonlike interpretasie van kuns. Dit word gedoen teen die agtergrond van die dood van Engela Buitendag (met wie Johan Buitendag in 1978 getroud is) wat op 07 Julie 2014 oorlede is nadat kanker 5 jaar vantevore by haar gediagnoseer is. Vier jaar gelede, in die boek onder redakteurskap van George Claassens en Fritz Gaum, God? Gesprekke oor die oorsprong en uiteinde van alles (2012), antwoord Johan Buitendag (2012b:331) hoe dit gekom het dat Martin Buber en Buitendag se vader, Roelf Buitendag (01 Mei 1921 - 19 Junie 2013) innerlik die werklikheid by hom gevestig het dat geloof en rede nie anders as eksistensieel en in verhouding tussen 'Ich' en ' $D u^{\prime}$ tussen God en mens en tussen mens en skepping $\left(=360^{\circ}\right)$ - verstaan kan word nie. Hierdie verhouding het vir hom nie ontstaan - en bestaan ook vandag nie vir hom - uit mirakelagtigheid nie. Dit bepaal wel sy totale eksistensie, bedoelende die tyd van kindwees en die kinderlike 'gebed en stryd' om te leer hoe om 'n skoenveter te knoop, totdat hy in Erlangen (Duitsland) vir doktorale studie oor Karl Heim, Friedrich Gogarten, Günter Altner, Karl Barth en Jürgen Moltmann se skeppingsverstaan navorsing gaan doen het, tot Maandag 07 Julie 2014 toe hy afskeid moes neem van Engela op haar sterfbed in die Mary Potter onkologie-afdeling van die Little Company of Mary Hospitaal in Pretoria en hy wat met 'n diep gevoel sê dat hy haar sien as 'n engel wat soos die Mona Lisa lyk, sy wat gesterf het maar lewe, en weer hyself wat lewe maar gesterf het. Om in teenwoordigheid van hierdie diepste eksistensiële Ich-Du van 'n eminente teoloog se werklikheidsverstaan te kon wees, dra daartoe by dat hierdie refleksie op aspekte in die akademiese oevre van Johan Buitendag kommunikasie in 'n binnekringsirkel is wat meer as van akademiese belang is.

\section{Die inloed van Kark Barth, maar met 'n kwalifiserende reserwe}

Die internalisering van 'n eksistensiële relasionele waarheidsbegrip beteken onder andere dat Johan Buitendag in die teologiese ensiklopedie dogmatiek nie van etiek skei nie. Hy kan die werklikheid nie waarneem sonder om bewus te wees van die uiterlike manifestasie (lees: etiese konsekwensies) van sy wetenskaplike ondersoek nie. Sy werklikheidsverstaan vooronderstel dus 'n onlosmaaklike 
verband tussen ontologie, epistemologie en etiek. Hy verduidelik die lens van waaruit hy die 'skepping van God' waarneem, metafories. In 1986 en 1988 skryf hy hieroor twee artikels, te wete 'Die skepping as gelykenis: 'n Beoordeling van die skeppingsleer van Karl Barth in die lig van die appèl van die ekologiese krisis' (Buitendag 1986:674-695) en 'En nou bly Skepper, skepsel, skepping - hierdie drie: 'n Teologiese profiel in die ekologiese debat' (Buitendag 1988:295-313).

Beide hierdie artikels beklemtoon 'n dinamiese werklikheidsverstaan, 'n verstaan van tyd as netwerk en die werklikheid as relasioneel (Skepper, skepsel en skepping). Buitendag reflekteer krities op Karl Barth se skeppingsleer en formuleer sy eie verstaan van ' $n$ 'teologie van die natuur.' Hierdie denke word 21 jaar later steeds gehoor wanneer hy in 2009 sy intreerede as Hoof van die Departement Dogmatiek en Christelike Etiek in die Senaatsaal van die Universiteit van Pretoria lewer (Buitendag 2009b:515-518). Buitendag se kritiese kwalifikasie van Barth is reeds in sy 1986- en 1988-artikels duidelik op te merk. Hy sien raak dat Barth se ontologiese 'verbondsbeginsel' as't ware vir Barth soos 'n 'kanon agter die kanon' funksioneer (Buitendag 1986:693; 1988:307). Buitendag (1988:693) wys verder ook op Barth se 'indifferente' houding jeens natuurwetenskap.

Buitendag se Skrifbeskouing kan nie los van hierdie saak verstaan word nie. In 'n artikel getitel "'God met ons": Gelowig nagedink oor die Skrif' gee hy aandag aan die 'volgorde' van epistemologie en ontologie in terme van openbaring (Buitendag 2008c:1131-1154). Hy oordeel dat die Protestantse skolastiek die begrip sola Scriptura oorspan het (Buitendag 2008c:1148). Daar behoort tussen die Skrif, die Woord en openbaring onderskei te word (Buitendag 2008c:1148) en daar moet 'n konstante relasie tussen geloof en rede in die verstaan en gebruik van die Skrif aanwesig wees. Ironies genoeg, voer dit tot 'n herwaardering van Nederlandse Geloofsbelydenis (Artikel 2) wat oor die 'twee boeke' van Godsopenbaring handel.

Konsistensie en verdiepende selftransformerende denke is ' $n$ kenmerk van 'n deurwinterde teoloog. Dit is opvallend om die raakpunte tussen die Johan Buitendag van die 1988's en die Johan Buitendag se akademiese intreerede as hoof van die Departement Dogmatiek en Christelike Etiek in 2009 met mekaar te vergelyk. Die titel van die gepubliseerde weergawe van die intrederede is "Nature as creation from an eco-hermeneutical perspective: From a "natural theology" to a "theology" of nature' (Buitendag 2009b:509-518). Steeds vorm die dialoog tussen teologie en natuurwetenskap die fokus. Soos dit op grond van sy Skrifbeskouing na vore kom, argumenteer Buitendag (2009b:509) in sy intreerede dat nie die verabsolutering van transendente openbaring of immanente kennis van die natuur 'n verantwoordelike verstaan van die werklikheid bied nie. Vir Buitendag is 'n 'teologie van (die) natuur' of 'n gekwalifiseerde natuurlike teologie 'n dialektiese derde opsie. Net soos in 1988 tree hy veral in gesprek met Karl Barth. ${ }^{1}$ Hy wys daarop dat Barth se

1.In hierdie opsig was Barth van mening dat die Bybel die bestaan van ' $n$ volkskerk sou legitimeer (in terme van die geskiedenis van die NHKA) teologiese onsin is (Buitendag 2009b:514; vgl. De Gruchy 1988:141-143). sogenaamde aversie teen enige natuurlike teologie verstaan moet word as reaksie teen die Nazi's se nasionaal-sosialisme (Buitendag 2009b:514) en dat Barth nie teen natuurlike teologie per se was nie. Die gevolg:

A critical-realistic approach opens up the possibility for a Christian natural theology to develop, in which members of the faithful can both interact from within a bio-cultural niche, as well as experience the coram Deo. (bl. 517)

Volgens Buitendag maak 'n evolusionêre epistemologie 'n dialektiese derde opsie moontlik (en hy dekonstrueer in positiewe sin beide Darwin en Barth). Hierdie aangeleentheid word in een van sy mees resente werke op besondere wyse verder uitgebou.

In Buitendag (2013) se huldeblyk aan sy vriend, die SuidAfrikaans-Oostenrykse Ou-Testamentikus James Alfred Loader, neem hy die vraag na die verhouding epistemologieontologie (= werklikheidsverstaan) weer op. Hy gebruik die bevinding van Eugène N. Marais ([1934] 2007) dat die termietnes as 'n organiese eenheid verstaan moet word as metafoor - en ag die wysheidspreuk 'gaan na die mier ... kyk na sy weë en word wys' (Spr 6:6) as dalk iets 'meer as net 'n wysheidspreuk' (Buitendag 2013:2 van 9). Vir hom word dit'n metafoor om te argumenteer vir die 'gedagte van panenteïsme (die immanensie van God in die skepping)' (vgl. sy bydrae tot die Julian Müller Festschrift, 'Panenteïsme as 'n funksionele, induktiewe konstruk in die gesprek tussen die teologie en die (natuur)wetenskap', Buitendag 2014). Buitendag is bereid om soos Clayton (2004:87) te verklaar: 'I find panentheism to provide the most adequate means available' (Buitendag 2013:5 van 9). Omdat hierdie bydrae bedoel is as ' $n$ huldeblyk aan Loader, werk Buitendag 'n bepaalde verstaan van 'wysheid' uit en verbind 'wysheid' met 'werklikheidsverstaan'. Wat is ' $n$ 'wyse werklikheidsverstaan'? Die mier se weë kan 'n 'wyse werklikheidsverstaan' versinnebeeld, naamlik dat die mier nie atomisties funksioneer nie, maar korporatief. Die totale gedrag van die enkele mier word van buite af (deur die koningin) bestier en gedetermineer en daar is dus ' $n$ morele band, wat 'alleen korporatief kollektief' verklaar kan word (Buitendag 2013:6 van 9). Menslike identiteit is die produk van die biologiese en omgewingsfaktore. Daar is dus meer in die skepping as wat empiries waarneembaar is. Vir Buitendag is 'n Sistematiese Teologie 'werklikheidsverstaan ... 'n ellips met twee brandpunte: 'n ontologiese en 'n epistemologiese' (Buitendag 2013:1 van 9). En dit moet in dade uitmond.

Etiek is daarom belangrik vir wat Buitendag as die mensdom van vandag se grootste krisis bestempel, te wete die ekologie. Die leemte wat die teologiese diskoers in die ekologiese debat laat, dra by tot die onaanvaarbare teologiese regverdiging van die mens se uitbuiting en vernietiging van die skepping (Buitendag 1988:297). Die skynbare volgorde wat Buitendag aan ontologie-epistemologie gee, roep die vraag na vore of hy nie sy postmoderne verstaan van die invloed van mag op die ekologiese debat nog duideliker as tot nou toe behoort te beskryf nie. Sien hiervoor sy kritiek op John Polkinghorne (2005; Buitendag 2011b). Buitendag (1988:307) kritiseer vir Jürgen Moltmann (1977:136-137) 
wat die ekologiese krisis as die keersy van die sosiale en politieke krisis van ons dag beskou. Sou hy na 21 jaar steeds hierdie kritiese standpunt huldig?

Dit is duidelik dat Buitendag (1988:308) die etiese implikasies van Karl Heim se verstaan van tyd as 'n netwerk en tyd as die basis van 'n werklikheidsverstaan waardeer (kyk Buitendag 1988:308-311). Die implikasies wat Buitendag met sy verbandlegging tussen 'tyd as netwerk' (werklikheid as relasioneel) en etiek ('kritiese solidariteit met die kreatuur' - Buitendag 1988:306) voorsien, kan tog nog duideliker geformuleer word. Hy beklemtoon die 'raaksien' van die 'totale skepping' en 'die eis wat die ekologiese debat dus aan die Christelike geloof stel' (Buitendag 1988:300). Hierdie 'kritiese solidariteit' met die 'totale skepping' blyk kernelemente van Buitendag se teologie van die natuur te wees.

\section{Paradigmas}

As dekaan van 'n veelkerklike teologiese fakulteit wil Buitendag nie voorgestel word as synde 'n teoloog van die 'Hervormde Kerk' nie (Buitendag 2012b:328), maar 'n belangrike onderdeel van Buitendag se vroeëre akademiese oeuvre het wel betrekking tot die Hervormde Kerk se teologiese konteks. Een so 'n voorbeeld is sy opstel 'Die paradigmas van "Kerk en wêreld 2000"' (Buitendag 1990:690-707), 'n voordrag wat hy by die destydse Hervormde Teologiese Vereniging gelewer het. In 1985 het die Nederduitsch Hervormde Kerk (NHKA) 'n studie met die titel Kerk en wêreld 2000 gepubliseer. Die doel van die studie was om vanuit die kring van die Hervormde Kerk na te dink oor die verhouding tussen kerk en wêreld en watter uitdagings die nuwe millennium aan die NHKA se kerkwees in die Suid-Afrikaanse konteks stel (NHKA 1985). In sy bydrae ondersoek Buitendag (1990:690-707) die aard van die 'paradigma' waaruit die studie vyf jaar tevore saamgestel is. Vir Buitendag (1990:700-701) is 'paradigma' - in terme van Thomas Kuhn (1962) se gebruik van die begrip - 'n epistemologiese raamwerk van waaruit en waarin daar kollektief oor gedeelde waardes gedink en modeloplossings vir gemeenskaplike vraagstellings gevind word (Buitendag 1990:691). Die begrip dien dus as 'n model vir wetenskapbeoefening. Dit lyk vir hom asof hierdie studie as 'n soort 'credo van die Hervormer' bedoel was (Buitendag 1990:704). Hy toon egter krities aan dat daar teenstrydige paradigmas in die studie aangetref word en volgens hom kom die dogmatiek daarin nie met die Hervormde Kerk se etiese praktyk ooreen nie (Buitendag 1990:703).

Dit is vir hom duidelik dat hierdie anomalie ' $n$ ernstige uitdaging aan die Hervormde Kerk stel (Buitendag 1990:700; 702; 706). In 'n sekere sin antisipeer Buitendag hiermee die kerkskeuring wat sedert 2007 tot vandag toe besig is om in die Hervormde Kerk plaas te vind. Buitendag se teologie is 'n belangrike 'katalisator' hiertoe (kyk later). ${ }^{2}$ Kerkskeuring

2.Die term 'katalisator' word hier bewustelik as metafoor gebruik wat nie ' analogiese raakpunt met die chemiese gebruik van die term het nie, maar wel 'n dogmenter dogmenhistoriese verwysing het. Buitendag is gedurende sy termyn as moderato in die periode $2004-2007$ as 'dwaalleraar' geëtiketteer toe hy die ideologie van
rassisme in die Hervormde Kerk se legitimering van apartheid en die ekklesiologiese is 'n negatiewe verskynsel. In positiewe sin kan gemeld word dat die Hervormde Kerk gedurende hierdie jubileejaar weer in 2014 as lidkerk van die World Communion of Reformed Churches (WCRC) toegelaat is ${ }^{3}$ nadat lidmaatskap in 1982 deur die destydse World Alliance of Reformed Churches (WARC), onder voorsitterskap van dr. Allan Boesak, gesuspendeer is. Onder sy moderatorskap word Boesak genooi om as verteenwoordiger van WARC die sinode van die Hervormde Kerk in 2007 toe te spreek. Johan Buitendag se akademiese en kerklike leierskap is die direkte aanleiding tot hierdie hertoelating tot die ekumeniese wêreld. Dit is ook sprekend dat Allan Boesak deur die Fakulteit Teologie van die Universiteit van Pretoria, onder dekaanskap van Buitendag, in September 2014 op die kampus van die Universiteit van Pretoria met 'n Festschrift vereer is (kyk Dibeela, Lenka-Bula \& Vellem 2014; vgl. Dreyer in druk).

Reeds in sy 1990-studie spreek Buitendag op ondubbelsinnige wyse sy kritiek teenoor die Hervormde Kerk se volkskerksiening uit. Dit is vir hom duidelik dat die Hervormde Kerk nie die eise van die veranderde situasie of konteks besef nie (Buitendag 1990:700). Wanneer hy sewe jaar later (in 2007, gepubliseer in 2008) as moderator van sy kerk die sinodale openingsrede lewer, beskryf hy hierdie visie met die titel 'Ecclesia reformata semper reformanda - die ongemaklike eis' (Buitendag 2008b).

\section{Kerkwees as gebeure}

Dit is interessant om op te merk dat die vraagstukke van die kerkwees in die huidige konteks deur Buitendag benader word vanuit sy waarderende paradigma van die waarde van natuurwetenskap vir teologie. Dit gebeur ook ten opsigte van sy verstaan van die betekenis van die nagmaal waar dit alkoholgebruik moet in- of uitsluit (kyk Buitendag 2000:1932). Soos elders in ander diskoerse gaan dit vir Buitendag ook in hierdie vraagstellings om die werklikheid wat hy as dinamies en persoonlik op eksistensiële wyse ervaar. Hy skryf sy fokus toe aan die insigte van die relatiwiteitsteorieë en die kwantumfisika dat 'alles in 'n proses van wording is'; dat die werklikheid 'n netwerk van potensialiteite is (Buitendag 2000:26, 28).

Die kwessie van die reële teenwoordigheid van Christus by die Nagmaal (praesentia realis) verbind Buitendag met sy verstaan van 'n dinamiese en persoonlike werklikheid. Daar kan dus nie vir hom 'n 'geïsoleerde fiksasie op die element (=

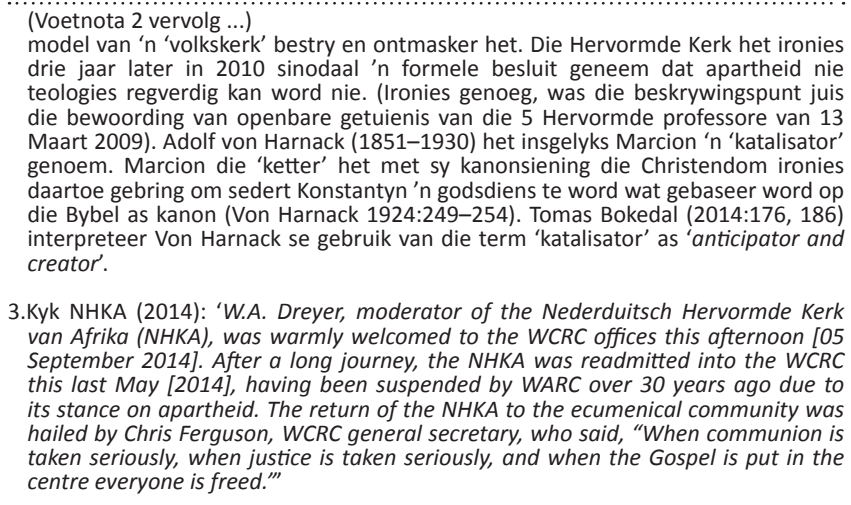
drie jaar later in 2010 sinodaal 'n formele besluit geneem dat apartheid nie teologies regverdig kan word nie. (Ironies genoeg, was die beskrywingspunt juis die bewoording van openbare getuienis van die 5 Hervormde professore van 13 Maart 2009). Adolf von Harnack (1851-1930) het insgelyks Marcion ' $n$ 'katalisator' genoem. Marcion die 'ketter' het met sy kanonsiening die Christendom ironies daartoe gebring om sedert Konstantyn 'n godsdiens te word wat gebaseer word op die Bybel as kanon (Von Harnack 1924:249-254). Tomas Bokedal (2014:176, 186) interpreteer Von Harnack se gebruik van die term 'katalisator' as 'anticipator and creator'.

3.Kyk NHKA (2014): 'W.A. Dreyer, moderator of the Nederduitsch Hervormde Kerk van Afrika (NHKA), was warmly welcomed to the WCRC offices this afternoon [05 September 2014]. After a long journey, the NHKA was readmitted into the WCRC this last May [2014], having been suspendec its stance on apartheid. The return of the NHKA to the ecumenical community was hailed by Chris Ferguson, WCRC general secretary, who said, "When communion is taken seriously, when justice is taken seriously, and when the Gospel is put in the centre everyone is freed."' 
wyn)' wees nie (Buitendag 2000:28). Die nagmaal gaan eerder oor Jesus se teenwoordigheid wat in 'n dinamiese gebeure, in wisselwerking tussen subjek en objek, in die viering van die nagmaal realiseer (Buitendag 2000:28). Die 'aktiwiteite van die gemeente rondom die nagmaal teenwoordig' is vir Buitendag (2000:29) 'n 'Christus-gebeure'. Hy beklemtoon die eenheid van die kerk wat in die nagmaal na vore kom en dat verskeidenheid ten opsigte van wat Jesus se teenwoordigheid by die nagmaal uitdruk, nie die eenheid mag belemmer nie. Daarom is sy artikel "'Saam een liggaam" (1 Kor 10:17) - Deelname van kinders aan die nagmaal' (Buitendag 2001:531-562) effens mosterd na die maal - om sy eie woorde anders te parafraseer. In die 2000-artikel skryf Buitendag dat ouderdom nie saak maak nie en dat die kwessie oor kindernagmaal 'grootliks bygelê' is (Buitendag 2000:19) en in sy 2001-artikel beskryf en argumenteer hy die saak volledig. Dit is duidelik dat hy dit as Hervormde Kerk-predikant doen, want hy bied dit aan as 'n voordrag by die jaarlikse predikantevergadering. Vir die Hervormde Kerk was dit spesifiek 'n kwessie en is dit steeds nie 'n afgehandelde besprekingspunt nie. Weer eens beklemtoon hy die eenheid van die liggaam van Christus (Buitendag 2001:546-547; vgl. Buitendag 2000:30-31).

Hoewel Buitendag in terme van die metafoor 'risoom' as spieëlbeeld van sy eko-teologie aan kerkwees in 'vloeibare' terme dink, beteken dit nie dat hy die kerk nie ook as instituut beskryf nie (Buitendag 2002c:2). In sy artikel, getitel 'Postliberale teologie as teologiese raamwerk vir die kerk se korporatiewe identiteit' (Buitendag 2002c:1-25) maak hy die opmerking: '[E]lke individuele stuk van 'n skaakspel vind immers sy sin en waarde in die omgewing waar dit is' (Buitendag 2002c:3). Vir Buitendag is een van die belangrikste eienskappe van die 'postliberale' teologie die belang van die gemeenskap of groep. Hierdie kollektiwiteit vind hy in 'evangelikaliese individualisme' afwesig (Buitendag 2002c:16)

Vanuit sy perspektief op post-liberale teologie as die raamwerk vir die kerk se identiteit, stel hy dit ook in hierdie geval duidelik dat hy relasie en netwerk voorop stel. Hy sluit by Cronje et al. (1991:31) se uiteensetting van die vernaamste doelwitte van 'n sakeonderneming aan (winsgewendheid, groei, markaandeel, sosiale verantwoordelikheid, welstand van werknemers, produktiwiteit en diens aan verbruikers (in volgorde van belangrikheid) om te argumenteer dat die kerk ook in 'n sekere sin soos 'n maatskappy is (Buitendag 2003a:354). Maatskappye (kerk) moet aandag gee aan die korporatiewe beeld wat hulle uitstraal (Buitendag 2003a:356). Die kerk behoort ook te vra wat die kerk se besigheid behoort te wees (Buitendag 2003a:357), wat die kerk se kompeterende voordeel is (Buitendag 2003a:358) en wat die kerk se waardetoevoeging tot mens en natuur binne 'n pertinente konteks is (Buitendag 2003a:359). Volgens hom is hierdie vrae die kerk se waardetoevoeging tot mens en natuur, en tegelyk wat hy meen die 'besigheid' van die kerk vandag behoort te wees.

\section{Betrokke refleksie}

Die metafoor 'dans' dien vir Buitendag (2002a:940-955) as vertrekpunt om sy siening van die 'genealogie van tyd en ruimte' te verduidelik. Hierdie metafoor steun op die kwantumfisika en gee vir hom 'n perspektief op 'n bepaalde interpretasie van die werklikheid. Hy stel dit soos volg: 'Die kwantumfisika se beskrywing van die werklikheid kan nie net as 'n model in die menswetenskappe aangewend word nie, maar die werklikheid is ook juis so' (Buitendag 2002a:942). Die ontologiese vloeibaarheid van die lewe vra 'n etiek wat voortspruit uit wat hy noem 'betrokke refleksie'. Hy haal 'n spreuk van 'n inheemse Amerikaner aan: 'O great Spirit, grant me that I won't criticize my brother until I have walked a hundred miles in his moccasins' (Buitendag 2002a:953). Om by wyse van spreke - in die sool van die inheemse boorling se velskoen te loop vra vir die postmoderne wetenskaplike om 'dansend' wetenskap te beoefen. Vastigheid, rigiditeit en monokulturaliteit rym nie met 'fleksibiliteit' nie. Inteendeel, Buitendag (2002a:953) sê: 'Ons moet dus ons dansskoene aantrek en betrokke oor ons onderwerp reflekteer.'

Al 'dansend' reflekteer Buitendag (2002b:291-304) op Karl Heim (1949) se werk Der christliche Gottesglaube und die Naturwissenschaft: Der evangelische Glaube und das Denken der Gegenwart. Hy fokus op Heim se verstaan van ruimte in die debat tussen die teologie en natuurwetenskap. Hierdie 'betrokke refleksie' gee aanleiding tot Buitendag (2002b:294) se spesifieke verstaan van eenheid en verskeidenheid: 'ruimte is die uitdrukking van 'n verhouding tussen twee pole' (Buitendag 2002b:297; vgl. Heim 1949:150). Dit het bepaalde implikasie vir Buitendag (2002b:302) se verstaan van die Christologie. In hierdie verband verwys hy soos volg na Walter Kasper (1977) se 'ekumeniese teologie':

Thus we can finally say what the pneumatic body of the Resurrection is: the totality of the person (not just the soul) that is finally in the dimension of God that has entered entirely into the Kingdom of God. Corporeality of the Resurrection means then: The whole person is finally with God. (bl. 151)

Die invloed wat Heim op Buitendag het, kan gesien word in die raakpunte tussen Buitendag se interpretasie van Heim se verstaan van tyd (Buitendag 2003b:15-28) en Buitendag se refleksie op Moltmann se skeppingsleer (en eskatologie) (vgl. Buitendag 1986:680, 1988:308-311, 2002a:942, 942, 950, 2002b). Eskatologie word beïnvloed deur die debat oor die verhouding tussen wetenskap en teologie. Volgens Buitendag (2003b:27) kom Karl Heim se insig daarop neer dat tyd as 'n netwerk verstaan behoort te word en dit beteken dat potensialiteit ' $n$ bepaalde ontologiese voorrang bo werklikheid en noodwendigheid kry. Tog bly die vraag: Hoe verander hierdie insig ons denke oor die eskatologie?

In die artikel 'Die wêreld as gelykenis: 'n Trajek om die middelterm van die "teologie" te vind' gee Buitendag (2003c:1063-1080) op dialektiese wyse uitdrukking aan die potensialiteit en die onmoontlikheid van teologiese spreke. Die vraag is: Hoe word die sake wat die afstand tussen God en mens veronderstel, oorbrug (Buitendag 2003c:1065)? Buitendag soek dus na 'n middelterm wat spreke vanuit menslike werklikheid oor 'n bomenslike werklikheid 
moontlik sou maak. Dit gaan hier oor hoe 'n mens enigiets van God kan weet. Buitendag (1988, 2003c:1071, 2009b) maan teen 'n eensydige verstaan van natuurlike teologie soos wat ' $n$ mens byvoorbeeld by Karl Barth vind. Dit is nodig om te onderskei tussen ' $n$ natuurlike kennis van God en kennis van die God wat uit die natuur afgelei en (ge-)openbaar word en is. Laasgenoemde is 'n menslike poging van verstaan en dit kom direk teenoor God te staan:

Natuurlike teologie is dan nie maar die vooronderstelling van ' $n$ openbaringsteologie nie, maar juis die afhandeling daarvan. Natuurlike teologie is nie bloot die 'voorportaal' van die openbaring nie, maar die prolepsis van die eskatologiese heerlikheid (Moltmann). (Buitendag 2003c:1076)

Gebaseer op hierdie dinamiese en relasionele verstaan van tyd sien Buitendag (2003c:1076-1078) die volgende as elemente van die kerk van die toekoms: sosiolinguistiese nisse (vgl. Buitendag 2002c), eendersheid-en-andersheid, markgeoriënteerdheid (vgl. Buitendag 2003a), publieke teologie en diens. Buitendag se gevolgtrekking is dat die uitdrukking 'wêreld as gelykenis' as die middelterm van betrokke teologie gesien behoort te word. Hierdie 'middelterm' word deur hom in 'n verskeidenheid opstelle uitgewerk - soms is die aanwesigheid van die 'middelterm' eksplisiet op die oppervlak van die argument te vind en soms is dit implisiet in die dieptestruktuur.

In 'n artikel oor die speelruimte tussen 'n fiksasie op die vrye wil van die mens (voluntarisme) en 'n fiksasie op 'n materialistiese predisposisie (natuur/gene - determinisme) bespreek Buitendag hoe 'gene' se werking verstaan behoort te word in die verstaan van menslike seksualiteit en spesifiek homoseksualiteit (Buitendag 2004b; vgl. Buitendag 2004c). Teenoor determinisme en voluntarisme kies hy vir die opsie van Nancey Murphy (1998), naamlik 'nonreductive physicalism' (non-reduktiewe fisikalisme). Hiervolgens behoort die werklikheid meer holisties verstaan te word. Die mens se seksuele oriëntasie is nie 'n 'keuse of slagoffer' nie (Buitendag 2004b:74). Die mens is ' $n$ biokulturele wese. Gene handel nie geïsoleerd nie en dus is sosiolinguistiese nisse 'veral ten opsigte van 'n bepaalde seksuele oriëntasie' belangrik (Buitendag 2004b:78). Hy beklemtoon die kerk se verantwoordelikheid omdat 'die liefdesgebod ... nooit gekompromitteer [kan] word nie' (Buitendag 2004b:78). Hierdie aangeleentheid word weer in sy artikel oor Luther se verstaan van die huwelik aangeraak en die vraag is of Luther nie tog die liefdesgebod wel relativeer met sy dialektiese verstaan van die huwelik nie. Enersyds is die huwelik nie sakramenteel nie maar as 'skeppingsordening' tog 'sakraal'. Is liefde dan net dié van die verhouding tussen 'n man en 'n vrou in huweliksverband? Buitendag (2007) verwoord sy verstaan van Luther soos volg:

Marriage is for Luther an institution which is therefore simultaneously worldly and sacred. It is secular because it is an ordinary earthly institution and in no way carries a sacramental meaning ... But it is also sacred because it is an ordinance of creation and was therefore instituted by God self. Yet it does not sustain faith nor does it prepare human beings for eternal life as a sacrament of faith. This dialectical view of marriage - law and gospel $-\ldots$ placed marriage in the greater context of God's relationship with creation ... it is important that [the two aspects of the] double movement should be held continuously in a dialectical tension with each other. (bl. 458)

\section{Betrokke teo-antropologiese refleksie en eko-teologiese kontoere}

Buitendag se refleksie op voluntarisme en determinisme lei hom na nadenke oor evolusie (Buitendag 2004c:868) en mond uit in 'n opstel getitel 'Günter Altner se jukstaponering van die denksisteme van Schweitzer ([1966] 2000) en Darwin ([1859] 1884) as resiproke korreksies' (Buitendag 2004c:865881). Hy argumenteer dat geen lewe ten koste van ander lewe geskied nie, en indien wel, dat die prys so klein moontlik moet wees. Die mens bevind sigself tussen 'enersyds ... 'n natuurlike determinasie [en] andersyds ... 'n sinsoekende selfbestemming' (Buitendag 2004c:873). In hierdie artikel wys hy op Altner se jukstaponering van die werk van Albert Schweitzer en Charles Darwin. Altner sien die uitdaging van die teologie daarin dat dit natuur en kultuur bevredigend moet kan verbind. Dus 'is dit vir hom belangrik dat die objektiwiteit van die seleksieteorie met die subjektiwiteit van die eerbied van die lewe moet korrespondeer', dus Darwin en Schweitzer (Buitendag 2004c:877). Hierdie is ' $n$ besondere bydrae om Altner se teologie te verstaan.

Buitendag se refleksie laat hom die moontlikheid van 'n transendente immanensie beklemtoon (Buitendag 2004c:877). Vrae wat in hierdie verband aan hom gestel kan word, is onder andere: Wat impliseer transendente immanensie vir hom? Is dit die moontlikheid van God? Of het dit meer te doen met die wyse waarop mens en natuur in konsonansie is? Is dit sleutel tot volheid en die leef van hierdie 'volheid'? Buitendag artikuleer skerpsinning: 'Lewenskwaliteit word nou so wyd moontlik opgevat deurdat dit 'n verskeidenheid van dimensies daarstel wat tyd-ruimtelike netwerke konsipieer waarbinne interafhanklikheid van die onderskeie enkelkwaliteite herkenbaar word' (Buitendag 2004c:876). Die vraag oor 'lyding' behoort volgens hom nie deur natuurlike seleksie beantwoord te word nie. Dit is vir hom belangrik dat 'n theologia naturalis deur 'n theologia naturae gekwalifiseer en selfs vervang word (Buitendag 2004c:879; vgl. Buitendag 2009b:509-518).

Dit kom daarom nie as 'n verassing dat Buitendag hom met die resultate van die Yale-skool besig hou nie. In 'n resente artikel, getitel 'Die noodsaaklikheid van habitat in ons definisie van menswees: Op soek na 'n eko-teologiese verstaan van menslike lewe' (Buitendag 2012c) argumenteer hy dat George Lindbeck se beskrywing van die mens se 'sosiolinguistiese nis' tekortkominge het as dit by 'n holistiese verstaan van die menslike persoon kom. In ander artikels kry hierdie aspek implisiet of eksplisiet aandag (Buitendag 2002c, 2003a, 2003c, 2004a, 2005a, 2009a, 2009b). Lindbeck het nie die ekologiese bedding van die mens 'toereikend verreken' nie (Buitendag 2012c:7). Buitendag vra vir 'n 'herwaardering van die Christelike antropologie wat met 'n 
groen hermeneutiek die Bybel benader' (Buitendag 2012c:7). Die erns maak met die eko-relasionele dimensie van die lewe vooronderstel die mens se partisipasie aan die omgewing (habitat) en 'n 'bepaalde waardesisteem vir die verstaan van menswees' (Buitendag 2012c:7).

In sy werk "“Anders dink anders doen: Op soek na 'n ekoteologiese perspektief op kloning' (Buitendag 2004a:402-422) bou hy voort op die gedagtes wat in die 2004b en 2004c artikels uitgewerk is. In hierdie artikel skryf Buitendag oor die etiese uitdaging waarvoor die mikrobiologie en genetegnologie die teologie te staan gebring het. Hy verwys spesifiek na die moontlikheid (en werklikheid?) van kloning (Buitendag 2004a:402). Ook hier (soos in Buitendag 2004b en Buitendag 2004c) gaan dit oor die verband tussen genetiese en (of) natuurlike determinisme en die mens se vermoë en (of) reg tot keuses. Soos voorheen beklemtoon Buitendag (2004a:408-412; 2004b:61-81) die gevaar van 'n gereduseerde mensbeskouing, wat die mens as biokulturele wese binne 'n netwerk van relasies en sosiokulturele nisse nie ernstig bejeën nie. Vir hom is die waardigheid en die uniekheid van die mens te midde van vrese oor onwaardigheid en identiteitsloosheid wat menslike kloning kan meebring, belangrik. Hy (Buitendag 2004a) stel dit soos volg:

Maar wat nou wel duidelik moet wees, is dat elke subjek 'n unieke nis het waardeur hy of sy gevorm word en waarin verantwoordelik gelewe moet word. 'n Definisie van menswees sal voortaan net nie meer gegee kan word tensy die omgewing daarin konstitutief is nie. (bl. 419)

Die vraag of mense gekloon kan (mag) word, is dus die verkeerde vraag, want mens kan nie gekloon word nie (Buitendag 2004a:418). Tog moet die aangeleentheid (net soos stamselnavorsing) nie deur die teologie geïgnoreer word nie. Die teologie het ' $n$ 'skeppingsverantwoordelikheid om God se teenwoordigheid in hierdie skepping te aktualiseer' (Buitendag 2004a:418).

Dit is duidelik dat Buitendag se teo-antropologie ' $n$ betrokke teologie van ekologie veronderstel. In 'n oorsigartikel oor 'liturgiese kosmologie' met as hoofopskrif 'Liturgie as fontein van die lewe' argumenteer Buitendag (2005b) dat ook rites (rituele) ekologiese kontoere het. Beide die sakramente nagmaal en doop het 'n tyd-ruimtelike oriëntasie. In die sakramentele ervaring sny kruis-en-dwarslyne en bevind gelowiges hulleself 'op 'n bepaalde oomblik voor die aangesig van God' (Buitendag 2005b:74). Sakramente is die wyse waarop geloof in die wêreld sigbaar word en etiek toegepaste dogmatiek word (Buitendag 2005b:76). Hy wys daarop dat die bydrae van Gordon Lathrop (2003) se boek Holy ground: A liturgical cosmology daarin gesien kan word dat liturgie as't ware op 'n ekologiese sensitiewe wyse tussen die twee bome van Genesis 2 en Openbaring 22 geplaas word en dat die 'derde hoek' daarvan na die 'ander boom' verwys, naamlik die droë hout van die kruis (Lathrop 2003:69; vgl. Buitendag 2005b:76). Op vindingryke wyse illustreer Buitendag dat werklikheidsverstaan en liturgie mekaar wedersyds beïnvloed. Ook liturgie is vir hom die sosiolinguistiese nis waarbinne geloof bestaan (Buitendag 2005b:78; vgl. Buitendag 2002c, 2003a). Hierdie gedagtes word verder uitgewerk en toegepas op die debat oor die verhouding tussen teologie en natuurwetenskap in sy artikel 'The Human Genome Project as a case study in the debate about the relationship between theology and natural science' (Buitendag 2005a:753-769).

Buitendag se 'eko-teologie' het veral relevansie vir sy verstaan van tyd en ewigheid (vgl. ook Buitendag 1986:680, 1988:308-311, 2002a:942, 942, 950, 2002b, 2003b). In sy artikel met die hoofopskrif 'Binne of buite die blokkie?' (Buitendag 2008a:320-344) formuleer hy die invloed van sy 'teologie van tyd' op onder andere die 'eskatologie'. Hy argumenteer ten gunste van die desakralisering van tyd en toon aan dat so 'n siening eties-teologiese implikasies het. Die kronologiese laaste dinge behoort onderspeel te word en daar behoort eerder na die 'eksistensiële finale dinge van hier en nou' gevra te word (Buitendag 2008a:329). Die vrae van die 'lewe na die dood', is die vrae van hier en nou: ' $[D]$ ie "temporalisering" van die eskatologie as die "kairologisering" van tyd is onaanvaarbaar' (Buitendag 2008a:340). In sy nadenke hieroor verwys hy na die toenemende belangstelling van sistematiese teoloë om die tydsdimensie na analogie van die triniteitsleer te verstaan. Hy maak veral melding van die invloed van teoloë soos Miroslav Volf en John Zizioulas (Buitendag 2008a:340). Buitendag betoog dat 'n netwerk wat die tyd van die mens (endogene tyd), die tyd van die wêreld (eksogene tyd) en die tyd van God (transendente tyd) in interaksie bring, die koers is om in te neem (Buitendag 2008a:340). Self doen hy dit gestand met sy beklemtoning van die begrip 'triangulasie' (kyk Buitendag 2009c:220-230).

In aansluiting by sy werk oor die 'liturgie as fontein van die lewe' (Buitendag 2005b) beskryf hy in hierdie opstel liturgie as die 'partisipatoriese betrokkenheid' wat deur middel van triangulasie 'n 'derde punt' tussen hemel en aarde vorm (Buitendag 2009c:228). Hy vind die lens oftewel model hiervoor in sowel die triniteitsleer as die skepping. Vir Buitendag (2009c:221) weerspieël die kerk as geloofsgemeenskap die Drie-enige God. God as Vader, Seun en Gees maak in God self 'ruimte vir ander' (Buitendag 2009c:222). Dit is die 'oopmaak van hierdie spasie' wat juis die 'skepping van tyd' daarstel (Buitendag 2009c:222). Dit is 'n skepping van 'n ruimte 'naas God'. 'Ruimte' moet egter nie ten koste van relasie funksioneer nie (Buitendag 2009c:223). Daarom behoort daar meer van perichoresis gemaak te word en minder van homoousias. So 'n siening open die deur op 'n 'sosiale Triniteit'. Die kern daarvan is 'andersheid' en 'verhouding' (Buitendag 2009c:224). Trinitariese teologie 'bied dus die moontlikheid om ontologie te verstaan as 'n dinamiese netwerk van vryheid en wedersydse afhanklikheid van persone' (Buitendag 2009c:224). In liturgie word kennis deur deelname oorgedra - die liturgie is in ' $n$ kragveld gesetel omdat dit ' $n$ relasie tussen persoon en energie vooronderstel - en derhalwe kom 'n mens (deur hierdie sake te trianguleer) by 'n koherente verstaan van die werklikheid uit (Buitendag 2009c:228). Vir Buitendag (2011b:1 van 9) is dit ' $n$ sine qua non dat epistemologie en ontologie mekaar 
wedersyds beïnvloed. In sy artikel 'Epistemology models ontology' - in gesprek met John Polkinghorne' (Buitendag 2011b) verskil hy van Polkinghorne (2005:85) wat meen dat epistemologie ontologie voorafgaan. Hy werk die verband tussen epistemologie en ontologie ook aan die hand van die triniteitsleer uit (Buitendag 2011b:8 van 9). Volgens hom dink Polkinghorne oor die Triniteit meer in 'ekonomiese' terme as 'immanent' (Buitendag 2011b:7 van 9).

Sy eksistensiële visie op tyd beïnvloed Buitendag se teologie wanneer hy sy standpunt oor die klassieke kerklike belydenis descendit ad inferna (neergedaal na die hel) onder woorde bring (Buitendag 2009a:386-393). Volgens hom behoort hierdie artikel in die Apostolicum nie ge-ont(de)mitologiseer te word nie. Dit moet eerder getransformeer word sodat dit kan korreleer met die teenswoordige insigte van die fisika ten opsigte van tyd en ruimte. Deur voort te bou op sy vorige werke oor tyd en ruimte (vgl. Buitendag 2002a, 2002b, 2003b, 2003c) verkies Buitendag (2009a:392) om die woord infernum nie met 'hel' te vertaal nie. Sy voorkeur is eerder 'n neutrale woord soos 'onder-wêreld'. Die rede daarvoor is nie in die eerste plek ' $n$ taal- of ' $n$ paradigmakwessie wat daartoe lei dat daar taalmatig verskillende betekenismoontlkhede is nie (dit ook), maar eerder omdat Buitendag daarop wys dat die hedendaagse insigte op die gebied van die fisika 'n ander eskatologie meebring. Hy verwys daarna as realistiese eskatologie waar tyd-ruimtelike kwessies nie liniariteit veronderstel nie, maar eerder 'n 'summary of faith' (Buitendag 2009a:392).

Buitendag is derhalwe krities ten opsigte van die tipiese Gereformeerde verstaan van die begrip 'sondeval'. Hy argumenteer dat die Ortodoksie belemmerend inwerk op die gesprek oor die verhouding tussen teologie en natuurwetenskap, hoofsaaklik as gevolg van 'n bepaalde verstaan van tyd as liniêre tyd. Dit het die 'debat onnodig problematiseer' (Buitendag 2012a:1 van 10). Die tradisionele verstaan van 'sondeval' het ' $n$ 'staanplek in Gereformeerde teologie' gekry as gevolg van 'n misverstand wat toe te skryf is aan Augustinus se vertaling van in quo in Romeine 5:12 (Buitendag 2012a:8 van 10).

\section{Betrokke ekklesiologie}

Gedurende Buitendag se termyn as voorsitter van die Algemene Kommissie van die Nederduitsch Hervormde Kerk van Afrika (NHKA) het hy veral op teologiese gebied leiding gegee in hierdie Kerk se moeisame proses van terugkeer na die ekumeniese wêreld. Twee sake het die kern van die ekklesiologiese debat gevorm. Die een is die imperatief om die NHKA te bevry van 'n sosiopolitieke en teologiese legitimering van apartheid en die ander is om die Kerk tot bekering te lei sodat die teologiese eis dat die Kerk één is, geïnternaliseer kan word. Die kritiese vraag wat Buitendag vra, is hoe die verhouding tussen eenheid en verskeidenheid in kerkwees daaruit behoort te sien (Buitendag 2006a:798-804; 2006b:354-359). Te midde van persoonlike en lasterlike vergruising het Buitendag se daadkragtige leiding die NHKA tot 'n 'kwantumsprong' gebring. ${ }^{4}$ In 2010 (en weer in 2011) het die NHKA sinodaal verklaar dat dit Bybels-teologies verkeerd was en is om apartheid te wil regverdig. Vanaf 2011 tot 2013 het die kerk stelselmatig deur'n skeuringsproses gegaan wat met hofsake oor vervreemding van kerklike eiendom gepaardgegaan het. In 2014 is hierdie litigasieprosesse steeds nie afgehandel nie.

In twee artikels verwoord Buitendag se oortuigings wat as 'betrokke ekklesiologie' beskryf kan word: "Nuwe wyn in nuwe sakke en die behoud van altwee": 'n Herbedinking van die Hervormde Kerk se identiteit aan die begin van die 21e eeu in Suid-Afrika' (Buitendag 2006b) en 'Coming in from the outside: A crucial event in the history of ecumenism of the Nederduitsch Hervormde Kerk' (Buitendag 2006a). Hy argumenteer vir die ideaal dat die NHKA in die 'derde millennium' inklusief en evangelies sal leef. In hierdie werke bied hy sy weergawe van die proses om weer by die destydse WARC (World Alliance of Reformed Churches) - vandag die WCRC (World Communion of Reformed Churches) - aan te sluit op die voorwaarde dat die teologiese regverdiging van apartheid as anti-evangelies erken word. Hierdie artikels skets 'n oorsig oor 'hoe ons tot hier gekom het' en vra kritiese vrae oor die identiteit en relevansie van die NHKA in die een-en-twintigste eeu. Die eerste artikel bevat die opsomming van sy openingsrede by die NHKA se 'nasionale Colloquium' wat gedurende 27-29 April 2006 op sy inisiatief plaasgevind het (Buitendag 2006b).

Die akademiese verwerking van Buitendag se 'uittree-rede' as moderator van die NHKA in 2007 het die sprekende titel 'Ecclesia reformata semper refomanda - die ongemaklike eis' (Buitendag 2008b:123-138). Die sinodesitting in 2007 het plaasgevind teen die agtergrond van Buitendag se leierskap en sy 'betrokke ekklesiologie'. Gedurende hierdie sitting het die NHKA gestem oor die verwydering van die woord 'volkskerk' uit die Kerkorde. Die debat het gefokus op die beskrywing en definisie van kerkwees soos geformuleer in die Kerkorde se Ordereëls 1 en 4 (Van Wyk \& Buitendag 2008:1461-1462). In sy 'uittree-rede' verduidelik Buitendag sy kritiese solidariteit met die NHKA se ekklesiologie deur na die Pauliniese teologie te verwys. Paulus se appèl op die gemeente van Korinte is 'om nie volgens die vlees te handel nie' (Buitendag 2008b:132) en sodoende die ware gesig van Christus te verberg nie. Dit is die opdrag van die kerk om Christus as die gesig van God na die wêreld te reflekteer (Buitendag 2008b:134). Wat in Buitendag se oeuvre nog uitstaande is, is sy siening op die gebeure in die NHKA na afloop van die 2007 en 2010 sinodesittings - 'n kerkgebeure wat nouliks sonder die invloed van sy direkte teologiese leiding verstaan kan word.

4.Van Aarde (in Van Aarde \& Dreyer 2011:2 van 6) berig soos volg oor die uitspraak wat T.F.J. Dreyer, Buitendag se opvolger as moderator in 2010 tydens die NHKA se 69ste Algemene Kerkvergadering gemaak het: '... die toekoms sal leer of die NHKA 69ste Algemene Kerkvergadering gemaak het: .... die toekoms sal leer of die NHKA op apartheid as sosio-politieke ideologie gebou is of op die eise van die evangelie van Jesus Christus.' Met instemming bestempel Dreyer die NHKA se besluit om 'onomwonde' te verklaar dat apartheid nie Bybels-teologies' geregverdig kan word nie (kyk Van Aarde 2011) as ' $n$ 'kwantumsprong'. Binne ' $n$ jaar daarna is ' $n$ 'akt van doleansie' deur ' $n$ groep beswaarde lidmate van die NHKA uitgereik. Buitendag (en Van Aarde) het die fokus van polities-fundamentalisties gedrewe aanvalle deur konserwatiewes geword. 


\section{Eksistensiële betrokkenheid}

Op minstens twee plekke in sy werke wys Buitendag $(1988,2004 c)$ na die dialektiese aard van lyding. Hy doen dit in terme van 'n holistiese werklikheidsverstaan wat verskillende vakdissiplines se insigte verdiskonteer en op ' $n$ holistiese mensbeskouing betrekking het. In beide hierdie werke van hom verwys hy na die skilderwerk van die Switser, Ferdinand Hodler (14 Maart 1853 - 19 Mei 1918).

Moontlik het Buitendag met hierdie skilderwerk kennis gemaak toe hy die Duitse eko-teoloog Günter Altner (20 September 1936 - 06 Desember 2011) bestudeer het (kyk Altner 1977:70-77, 1980). In sy artikel oor die 'ekologiese krisis' skryf Buitendag (1988) die volgende:

Offervaardigheid en lydingskap vervang [dan] 'n Franciskaanse askese. Na en uit die weerstand moet ook die berusting volg (Bonhoeffer). Dit is eerbied vir die lewe en ontsag vir die dood. Die kuns van die Switserse skilder, Ferdinand Hodler, illustreer hierdie gedagte treffend. Dit getuig van 'n deurleefde rousmart na die dood van sy vrou Valentine Godé-Dorel .... [A]ksie en passie deur lyding verenig, het tot mekaar te staan gekom soos geskiedenis en natuur. Sodoende is 'n nuwe dimensie in die geheimenis van die skepping op die voorgrond gebring. (bl. 310-311)

Sestien jaar later verwys hy weer na die werk van Altner ('n sitaat wat gedeeltelik reeds vroeër in hierdie artikel gebruik is):

[D]aar [is] geen lewe wat nie ook ten koste van ander lewe geskied nie en andersyds is [dit] belangrik dat die prys altyd so klein moontlik moet wees. Die eenheid van die lewe word alleen begryp en gedien as die dood ónontkombaar verstaan en ervaar word. (Buitendag 2004c:870)

Op 07 Julie 2014 is Buitendag se vrou, Engela, aan kanker oorlede nadat sy in 2009 daarmee gediagnoseer is. ' $n$ Vyfjaarstryd teen kanker het dit voorafgegaan. Terugskouend gesien, is die verwysings na Hodler 'n vooruitskou - respektiewelik 10 en 26 jaar later - op die eksistensiële ervaring van die eko-teoloog Johan Buitendag se eie betrokke hermeneutiese habitat, Skrifbeskouing en teologie van die natuur. Die werk van Hodler waarna Buitendag in die twee artikels verwys is 'n reeks skilderye wat Hodler van sy vrou Valentine Godé-Dorel geskilder het. ${ }^{5}$ Dit beeld sy sterwende vrou uit en die sterwensproses waardeur sy gegaan het (kyk Bernhard C. Pestalozzi 2002). Dit beeld boweal die ontologie, epistemologie en etiek van dié een uit wat besig is om te kyk hoe iemand vir wie hy so lief is, besig is om te sterf (Figuur 1 - Figuur 7). ${ }^{6}$

\footnotetext{
5.Die portrette deur Ferdinand Hodler (1853-1918) is beelde wat in die openbare domein beskikbaar is: 'When a work's copyright term ends, the work passes into the public domain. Works in the public domain are those whose intellectual property rights have expired. In the European Union, copyright stretches across a creators' lifetime plus 70 years after their deaths' (http://en.wikipedia.org/wiki/Public_domain)

6.In die Hervormde Kerk Pretoria-Oos waar die Buitendag-familie as lidmate ingeskakel het, is 'n samevatting van ' $n$ huldeblyk deur Johan Buitendag by Engela se begrafnis op 12 Julie 2014 gepubliseer in die gemeenteblad Polsslag onder redakteurskap van Louise Geyser (2014:42). Hierdie huldeblyk verwoord nie net die pyn van die Buitendags, veroorsaak deur hulle stryd teen die apartheidsideologie in die Hervormde Kerk nie, maar ook die pyn van 'n analogie van Ferdinand Hodler se die Hervorn skilderye van sy sterwende eggenote. ' $n$ Ekserp vanuit Johan Buitendag se huldeblyk lees soos volg: 'Hoe sal ek met woorde reg aan my liewe vrou, Engela, kan laa geskied? Sý is die een wat my lewe vol gemaak het. Sy is my alter ego, ja 'is', want dit sal nie verander nie. Vir my sal sy altyd by my wees ... Familie en Vriende, die liefde wat ons van julle oor die jare ervaar het, en ek in die besonder die afgelope paar dae, kan nie met woorde uitgedruk word nie. Julle het ons gedra deur tye waarin veral Engela diep emosies ervaar het. Ek verwyt my dikwels dat my stryd
}

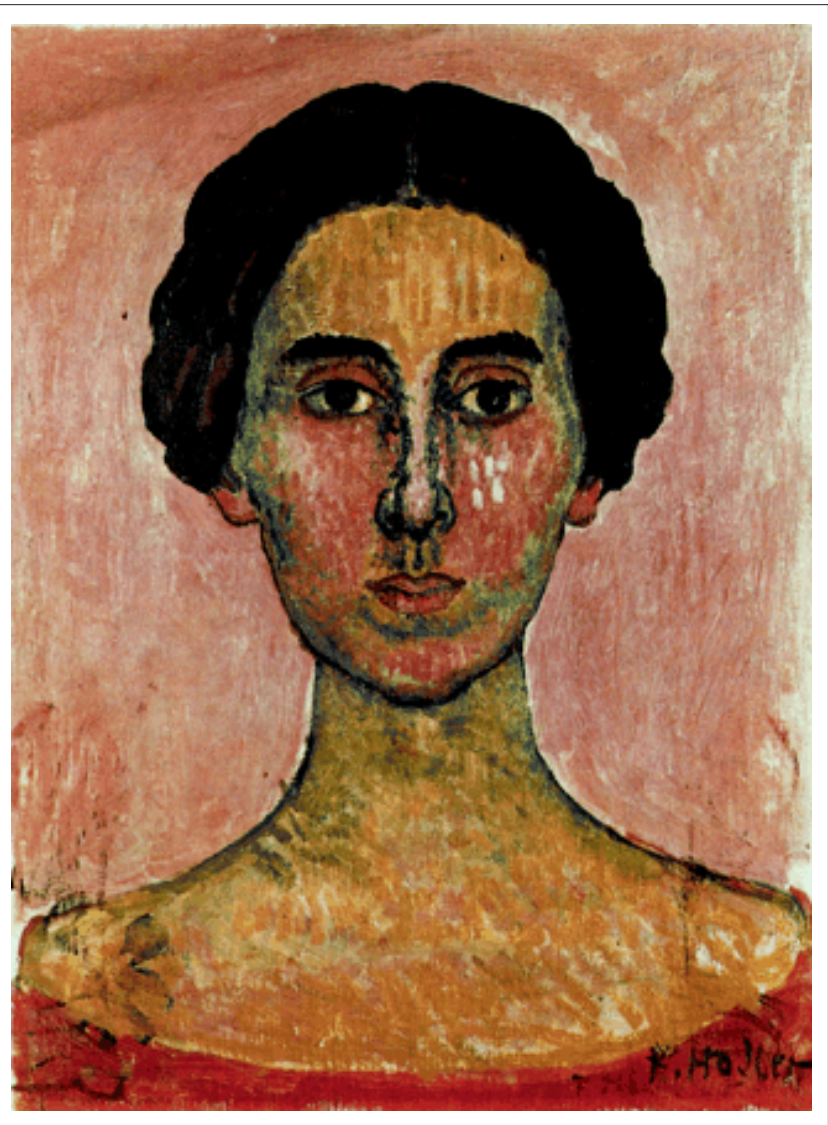

Bron: Pestalozzi, B.C., 2002, 'Looking at the dying patient: The Ferdinand Hodler paintings of Valentine Godé-Darel', Journal of Clinical Oncology, viewed 07 August 2014, from http://jco. ascopubs.org/content/20/7/1948.full

FIGUUR 1: Die jeug - portret geskilder in 1912, geskets in skadu's van rooi wat Godé-Darel as 'n pragtige, gesonde jong vrou uitbeeld:

In elke mens se lewe (en in hierdie geval, ook die teologie) is daar sprake van meerdere verhaallyne. In sy teorie oor literatuur, wys Eberhard Lämmert ([1955] 1972) daarop dat waar daar meerdere verhaallyne voorkom, dit belangrik is om die verband te bepaal. Gerárd Genette ([1972] 1980:113160) gebruik die begrippe 'prolepsis', 'analepsis' en 'ellipsis' om die kompleksiteit van die verhouding tussen meerdere verhaallyne te beskryf. Hierdie kompleksiteit kan selfs in 'n enkele verhaallyn (lewensvertelling van ' $n$ individu of groep) voorkom. So byvoorbeeld kan die eerste jare van 'n individu die intrige en selfs die lotgeval van die latere jare antisipeer (dit wil sê die een is ' $\mathrm{n}$ 'prolepsis' van die ander). Dit is ook moontlik dat 'n vroeëre verhaal (bv. vanuit die voorgeslagte, of 'n vorige periode) 'n 'prolepsis' vorm van 'n nuwe, heersende verhaal waarvan die intrige daarvan nie

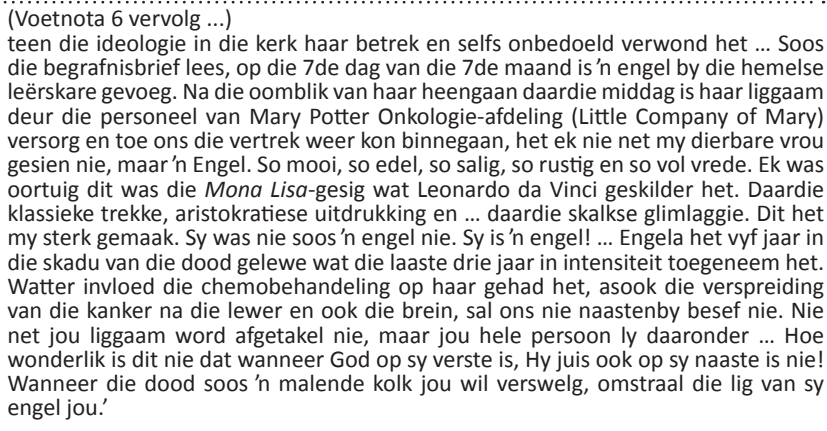
die begrafnisbrief lees, op die 7de dag van die 7de maand is'n engel by die hemelse leërskare gevoeg. Na die oomblik van haar heengaan daardie middag is haar liggaam deur die personeel van Mary Potter Onkologie-afdeling (Little Company of Mary) versorg en toe ons die vertrek weer kon binnegaan, het ek nie net my dierbare vrou gesien nie, maar'n Engel. So mooi, so edel, so salig, so rustig en so vol vrede. Ek was oortuig dit was die Mona Lisa-gesig wat Leonardo da Vinci geskilder het. Daardie klassieke trekke, aristokratiese uitdrukking en ... daardie skalkse glimlaggie. Dit het my sterk gemaak. Sy was nie soos'n engel nie. Sy is'n engel! ... Engela het vyf jaar in my sterk gemaak. Sy was nie soos' $n$ engel nie. Sy is' $\mathrm{n}$ engel! .... Engela het vyf jaar in die skadu van die dood gelewe wat die laaste drie jaar in intensiteit toegeneem het. Watter invloed die chemobehandeling op haar gehad het, asook die verspreiding van die kanker na die lewer en ook die brein, sal ons nie naastenby besef nie. Nie net jou liggaam word afgetakel nie, maar jou hele persoon ly daaronder ... Hoe wonderlik is dit nie dat wanneer God op sy verste is, Hy juis ook op sy naaste is nie Wanneer die dood soos ' $n$ malende kolk jou wil verswelg, omstraal die lig van sy engel jou.' 
sonder die vorige kragte na behore verstaan kan word nie (vgl. Van Wyk 2014:1 van 10).

Beide die medeouteurs van hierdie jubileumartikel (Andries van Aarde en Tanya van Wyk) was as vriende bevoorreg om saam met die Buitendag-gesin die laaste ure van Engela Buitendag mee te leef. Johan Buitendag se smart, geïnternaliseerde teologie en eksistensiële geloof het kerugmatiese kwaliteit. Die skilderye van Ferdinand Hodler

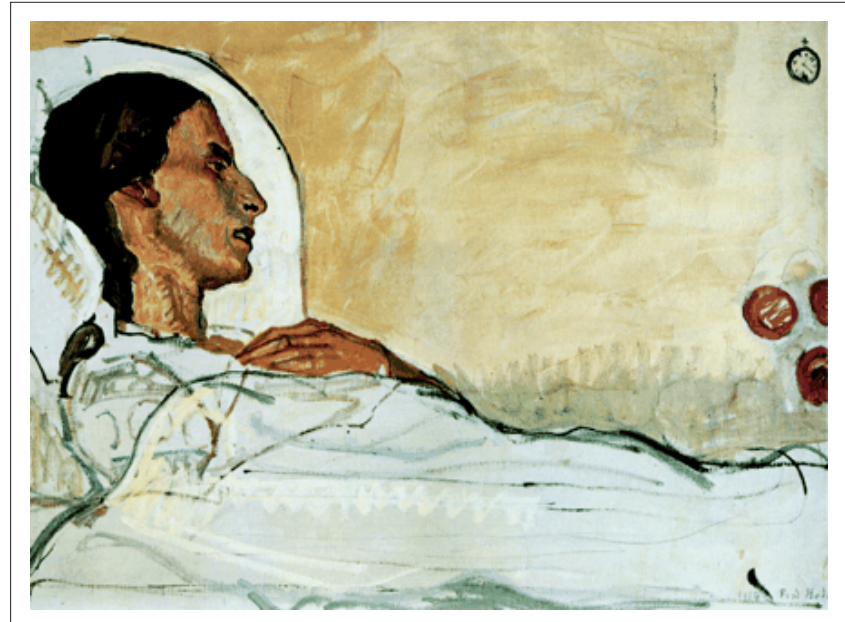

Bron: Pestalozzi, B.C., 2002, 'Looking at the dying patient: The Ferdinand Hodler paintings of Valentine Godé-Darel', Journal of Clinical Oncology, viewed 07 August 2014, from http://jco. ascopubs.org/content/20/7/1948.full

FIGUUR 2: Die siekte - Godé-Darel in 1914 as bedlêende pasiënt na haar tweede operasie, geskets met rose en horlosie.

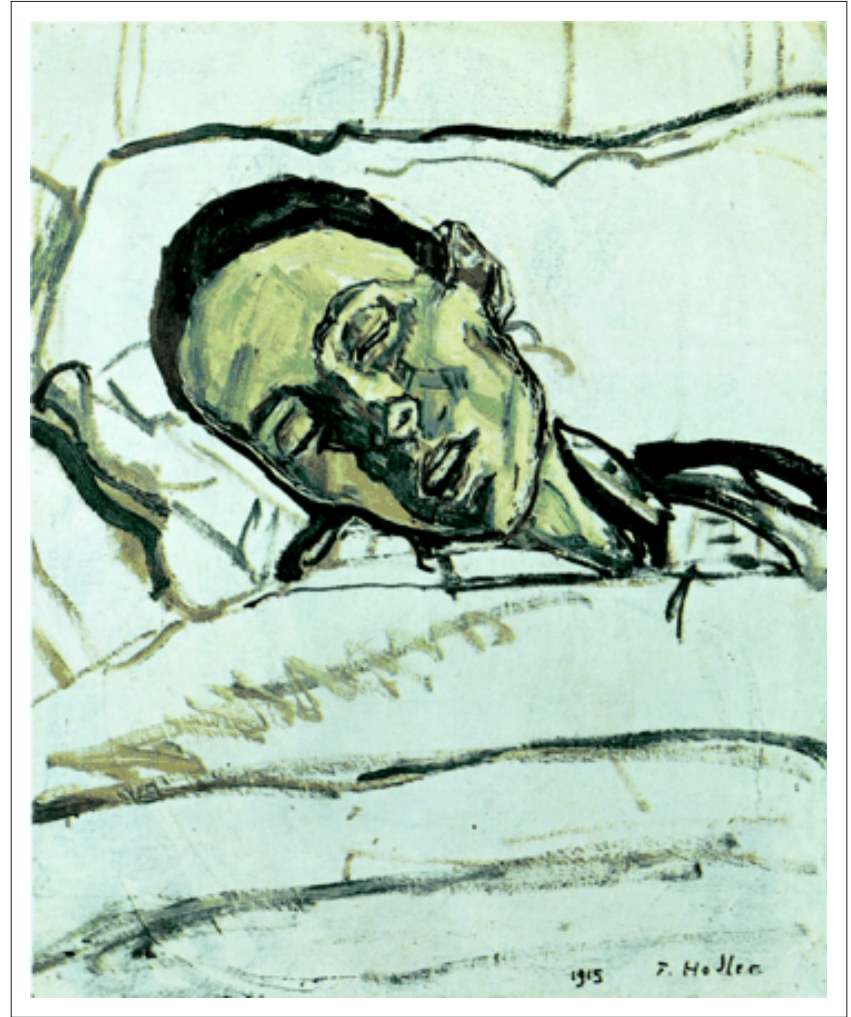

Bron: Pestalozzi, B.C., 2002, 'Looking at the dying patient: The Ferdinand Hodler paintings of Valentine Godé-Darel', Journal of Clinical Oncology, viewed 07 August 2014, from http://jco. ascopubs.org/content/20/7/1948.full

FIGUUR 3: Die moegheid - geskilder op 02 Januarie 1915; Godé-Darel as pasiënt wat slaap met gelaatskleure skerper, hoekig, beenderig en oë toe.

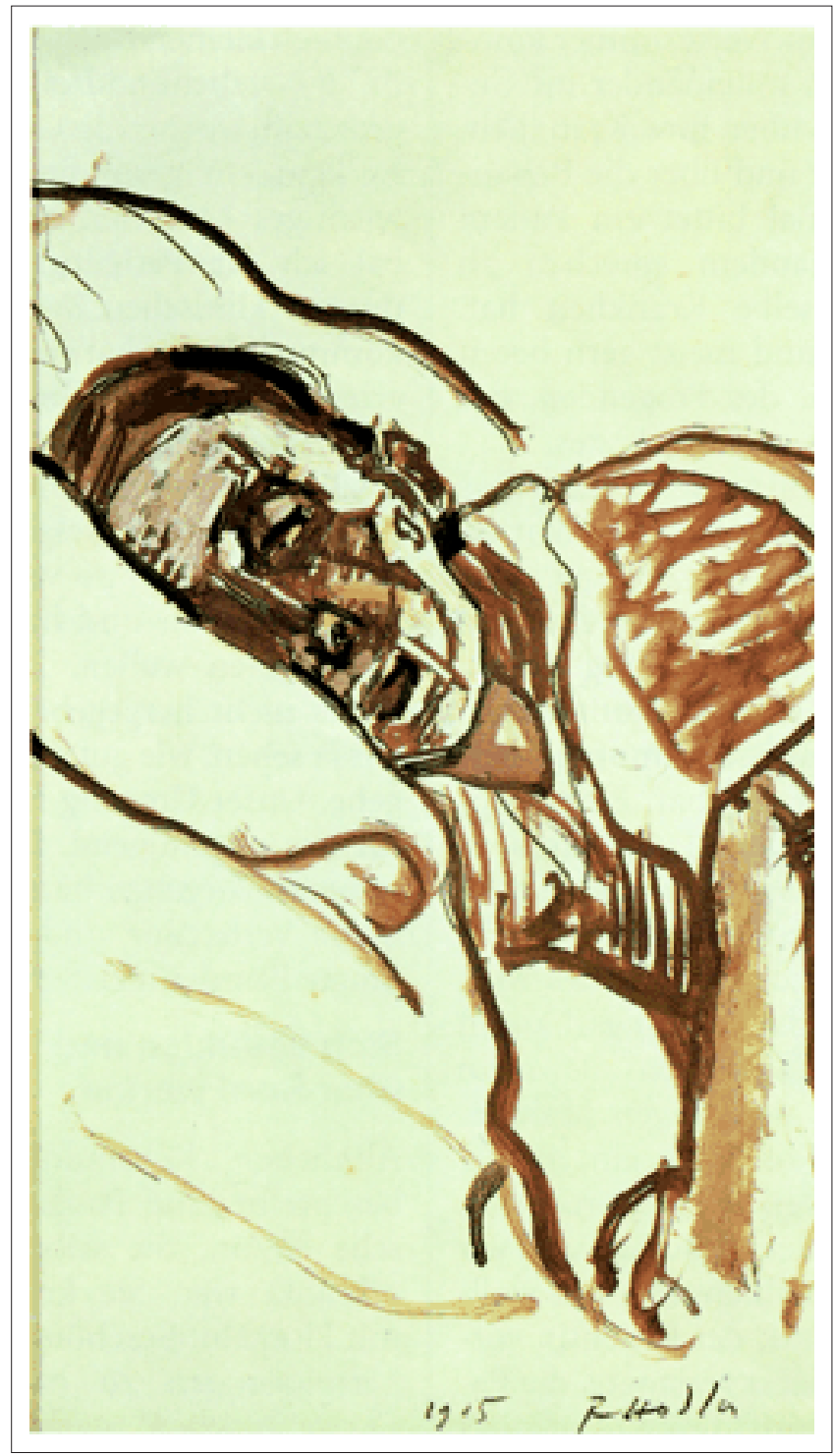

Bron: Pestalozzi, B.C. 2002, 'Looking at the dying patient: The Ferdinand Hodler paintings of Valentine Godé-Darel', Journal of Clinical Oncology, viewed 07 August 2014, from http://jco. ascopubs.org/content/20/7/1948.full

FIGUUR 4: Die pyn - skildery van die sterwende Godé-Darel met kop diep vervalle in die kussing, maar wat vir die laaste keer met Hodler praat, geskets op 19 Januarie 1915.

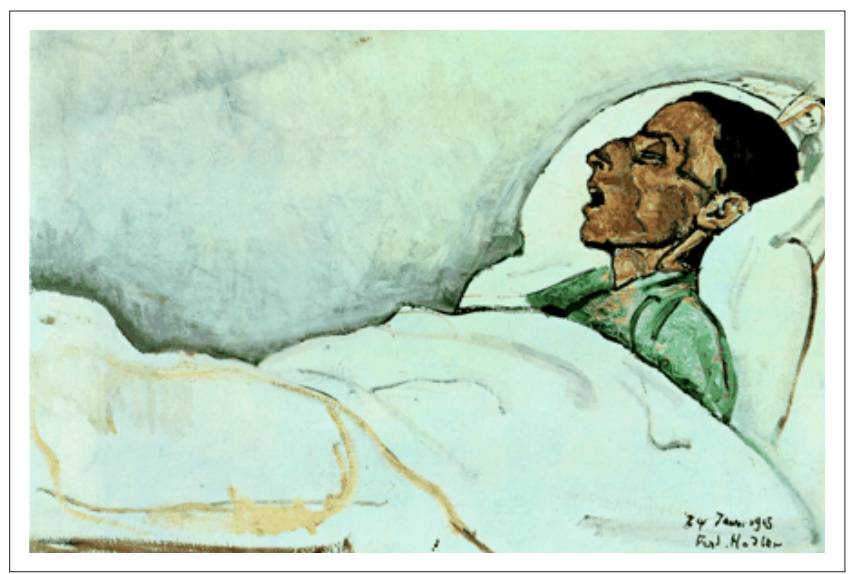

Bron: Pestalozzi, B.C., 2002, 'Looking at the dying patient: The Ferdinand Hodler paintings of Valentine Godé-Darel', Journal of Clinical Oncology, viewed 07 August 2014, from http://jco. ascopubs.org/content/20/7/1948.full

FIGUUR 5: Die worsteling - 'n dag voor Godé-Darel se sterfte, in koma en mond wyd oop maar niemand kan meer met haar kommunikeer nie. 


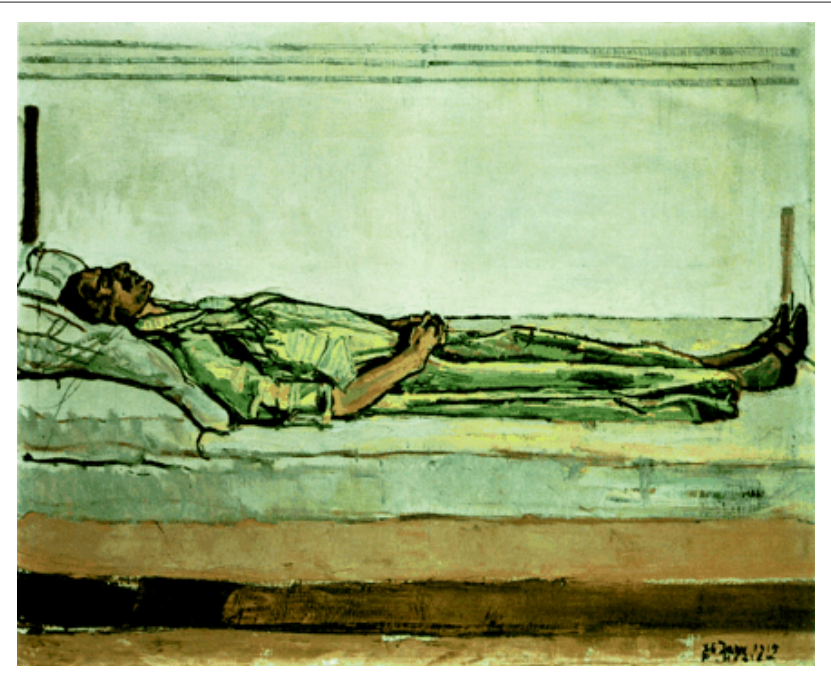

Bron: Pestalozzi, B.C., 2002, 'Looking at the dying patient: The Ferdinand Hodler paintings of Valentine Godé-Darel', Journal of Clinical Oncology, viewed 07 August 2014, from http://jco. ascopubs.org/content/20/7/1948.full

FIGUUR 6: Die dood - die laaste portret van Godé-Darel nadat sy gesterf het.

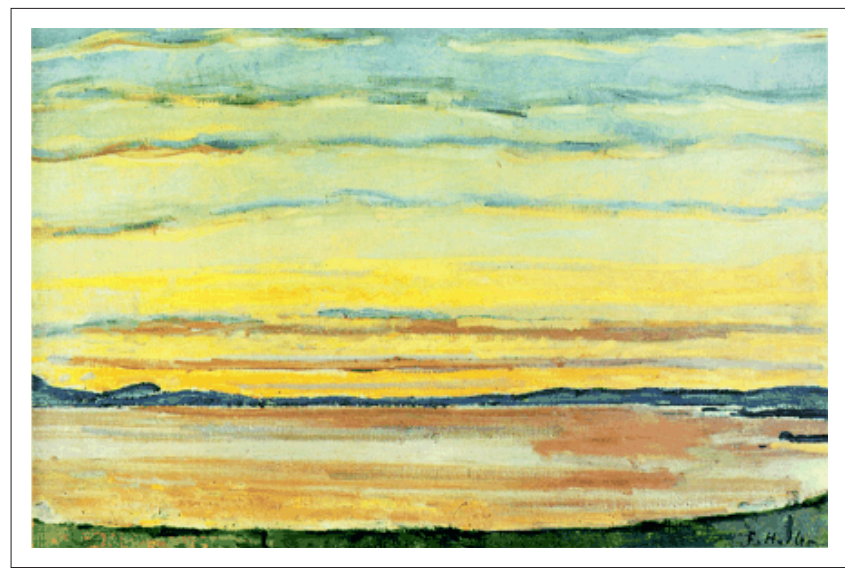

Bron: Pestalozzi, B.C., 2002, 'Looking at the dying patient: The Ferdinand Hodler paintings of Valentine Godé-Darel', Journal of Clinical Oncology, viewed 07 August 2014, from http://jco. ascopubs.org/content/20/7/1948.full

FIGUUR 7: Sonopkoms oor die Genève-meer - 'n prentjie wat oor en oor deur Hodler geskilder is met ' $n$ visie vanaf die plek waar Godé-Darel gesterf het.

is 'n spieël en verskaf kosbare memoires. Dit is as't ware 'n prolepsis van persoonlike eksistensiële betrokkenheid van Johan Buitendag se eko-teologie - van 'n dialektiese sistematiese teoloog wat dialektiek van lewe en dood nie net verstaan nie maar ook gelowig coram Deo uitleef.

\section{Outobiografiese betrokkenheid}

Byterugskouekanekmylewensloopas'ngeloofstrajekbeskryf waarin my eksistensiële ervaring van God en voortdurende bewus-wees van God se teenwoordigheid in my lewe geïntegreer is. Ek kan my geloof nie kronologies verduidelik nie en God ook nie klinies analiseer nie. My verhouding met God kan nie na 'n enkele Damaskuservaring teruggevoer word nie. Tog het ek in my lewe 'n voortdurende integrasie van geloof én rede beleef. Dit is die ontologiese bedding waaruit my epistemologie gegroei en vorm aangeneem het.

7.Hierdie beskrywing is ' $n$ aanpassing van Johan Buitendag (2012b:328-347) se beskrywing van sy eie teologie in gesprek met Frits Gaum.
Binne hierdie bedding het ek onder die diep indruk van die groter werklikheid buite en rondom my gekom. Die tema van my navorsing, 'skepping en ekologie,' het vorm aangeneem en daardeur is ek toenemend altyd van die natuur, van die ander wetenskappe, van die heelal bewus.

Ek is met Karl Barth se teologie van die 'Gans-andersheid van God' en die 'loodregte spreke van bo' grootgemaak. Danksy my pa het ek ook met Martin Buber se teologie grootgeword, en is dit die persoonlike ontmoeting met God, wat treffend deur Buber as 'I and Thou' beskryf is, wat my die sterkste aangespreek het. Op die spoor van die teoloog Sally McFague, by wie ek aanklank vind, praat ek dus in hierdie opsig nie óór God nie, maar eksistensieel mét God. Al verwys ek nog na Barth se werk terug, het ek tog in 'n groot mate van hom verwyderd geraak en dink ek al hoe meer induktief ten einde met die waarheid van God in ontmoeting te tree. Dus meen ek dat Emil Brunner eerder as Karl Barth korrek was oor die moontlikheid van 'n menslike bevatlikheid van God se openbaring.

Ek beleef God in die teenwoordige tyd eksistensieel, maar transendeer onmiddellik die engheid daarvan. Saam met Siprianus verklaar ek dat God ons Vader is, en die kerk ons moeder en dat ons die werklikheid van die teenwoordigheid van God kollektief in die kerk ervaar. Maar ek wil die sirkel wyer trek en ook van die kosmiese dimensies van God se versoening en teenwoordigheid praat. God is die God van liefde - hierdie liefde word by uitstek deur inklusiwiteit gekwalifiseer. Dalk sou 'n mens van 'n kosmiese inklusiwiteit kon praat. Juis hierdie allesomvattende liefde van God plaas 'n ontsettende appèl op my om die insluitende liefde van God in Christus in my lewe, ook en veral binne en met inbegrip van die kosmos, gestalte te laat kry. So is die ontologiese bedding wat ek bo as die bron van my epistemologie beskryf het, ook die bron van my etiek.

Vir my is daar dus 'n besliste verband tussen ontologie, epistemologie en etiek. In my teologiese arbeid het hierdie verband uitgekristaliseer in hoe ek 'tyd' en 'ruimte' verstaan en dit kom in vele aspekte van my teologie tereg, veral in my argumente wat handel oor die waardevolle insigte vir teologie wat uit die dialoog tussen teologie en ander wetenskappe verkry word.

Neem die skeppingsverhale as voorbeeld en kyk na wat 'n tyd-ruimtelike lees van Genesis 1 oplewer. Die weggevoerde Judeërs verkeer in 'n 'tyd' en 'plek' waar dit vanuit hulle tyd-ruimtelike situasie in Babel blyk dat die God van die Judeërs se 'tyd' en 'plek' tot 'n einde gekom het. Dan kom die Priesterlike skrywer(s) met die gedig in Genesis 1 en 'tyd' en 'ruimte' word deurgaans deur hierdie (na-eksiliese) skrywers in ag geneem. Dit begin nie by die wegvoering van die Suidryk (586 v.C.) nie, maar in die 'begin' en die verhaal word van die 'eerste oomblik' geskryf. Die Priesterlike skrywer(s) gebruik tyd as die matrys van die skepping: dag en nag, ses dae plus die sewende dag, maar hierdie keer sonder 'n nag. Die God van Israel is van ewig af God en sal 
vir ewig God wees. Die skrywer(s) maak ook so met ruimte. In kleiner wordende sirkels ontplooi hulle hulle verhaal. Lig, lug en grond is die formele aspek van die eerste drie dae, waarop die inhoudelike bewoners van die laaste drie dae volg, naamlik die plante, voëls, visse, diere en mense. 'n Mens sou ook 'n indeling uit die ekologie kon hoor: die ekosfeer à atmosfeer à hidrosfeer à troposfeer à biosfeer (vgl. Buitendag 2012c). Die mens het 'n opdrag gekry om te werk om te kan eet en die saad en vrugte vra sorg en arbeid sodat dit geoes kan word. Dus is arbeid en sorg die opdrag van die mens en nie vernietiging en oorheersing nie. Hieruit is die sterk etiese opdrag aan die mens duidelik. Binne hierdie tyd-ruimtelike 'dans' blyk dit dan ook uiteindelik dat die mens nie die hoogtepunt van die skepping is nie - nie dag ses nie, maar dag sewe, die Sabbat is die klimaks. Híér is God en mens harmonies saam in die skepping, met ' $n$ oop einde.

As die vraag dus beantwoord moet word oor waar God dan vandaan kom, is daar altyd vanuit my teologiese perspektief 'n teenvraag, of die bevraagtekening van die vraag (question the question). My navorsing het my ook met Stephen Hawking se insigte bekendgemaak en hy postuleer dat daar nie 'n eerste oomblik van tyd was nie, omdat tyd en ruimte nie twee aparte sake is nie en tyd nie sonder ruimte kan bestaan nie. Dus is die vraag aan die vraag oor God se oorsprong eintlik of dit regtig so is dat alles ' $n$ begin moet hê. Thomas Aquinas het geoordeel dat dit nie oor die tydelikheid van skepping en die ewigheid van God gaan nie, maar dat die vraag na die oorsprong eerder daarop dui dat die skepping op God aangewese is. Die neurowetenskappe se antwoord op die vraag oor die oorsprong van God is dat God volstrek in die menslike bewussyn bestaan. Danah Zohar verwys byvoorbeeld na 'n sogenaamde 'God-kol'.

Ek meen daarom nie dat God gevind kan word in'n klomp feite of proposisies of 'n persoonlike ervaring wat tot uitdrukking gebring word nie. Eerder is God te vinde in 'n netwerk van verhoudings wat deur 'n voortdurende wisselwerking plaasvind. Binne hierdie relasionele werklikheid vra ek nie die kliniese vraag na oorsprong en mag nie, maar eerder (aldus die skeppingsverhaal) die inklusiewe vraag na liefde en betrokkenheid.

Vincent Brümmer (2005) het in sy boek, Ultiem Geluk, aangetoon dat die mens nie binne in hom- of haarself sin sal vind nie. Sin kom dus nie net van binne af nie, maar ook van buite my.

Ek meen dat die kerk vir baie lank die mens se 'andersheid' met die natuur ten koste van die mens se 'eendersheid' met die natuur beklemtoon het. Ons herinner onsself graag daaraan dat ons deur God aangespreek kan word en dat ons, anders as diere, ons situasie kan oorstyg en toekomsverwagtings het - dit is wat ons volgens onsself uniek maak. Biologiese insigte het egter uitgewys dat ons nie so uniek is as wat ons gedink het nie. Tog kan dit nie wat ons in Genesis 1:26a lees ('Toe het God gesê: Kom Ons maak die mens as ons verteenwoordiger, ons beeld'), geïgnoreer word nie. Genesis 1:26a behoort saam met Genesis 3:22a gelees te word: 'Toe het die Here God gesê: Die mens het nou soos een van Ons geword deurdat hulle alles kan ken.' Om alles te ken, is die ontluiking van 'n morele bewussyn. So gesien, word die uitdrukking 'beeld van God' verstaan as die vermoë om tussen goed en kwaad te kan onderskei en etiek word gesien as konstitutief aan menswees (kyk Buitendag 2011a).

Die beeld van God in die mens ten opsigte van die ander rondom my en ten opsigte van myself word as appèl verstaan: Is ék die beeld van God? Weerkaats ek die inklusiewe en opofferende liefde van Christus na ander uit?

Die Gereformeerde Ortodoksie se verstaan van die sondeval, met die klem op die 'val' het die debat tussen teologie en natuurwetenskap geproblematiseer. Daarby is dit vir my duidelik dat die interpretasie van Augustinus van Romeine 5:12 (gegrond op die Latynse teks) verkeerd was. Paulus wou die verband tussen sonde en dood bespreek en het gepoog om te sê dat sonde ' $n$ universele verskynsel is en dat geen mens hiervan vrygespreek is nie. Paulus probeer nie sê dat almal aan Adam se sonde skuldig is nie. Om dit so te stel: ons erf die menslike genoom van Adam en nie Adam se sonde nie.

Biologiese dood het niks met sonde te doen nie, soos dit ook deur Jürgen Moltmann beklemtoon is. Mens moet egter nie die fout maak om hierdie vraag met die teodisee-vraagstuk te verwar nie. Boosheid en gebrokenheid is 'n gegewe. Die probleem is egter wel die wyse waarop die Christelike kerk deur die eeue gemeen het dat daar ' $n$ 'val' sou plaasgevind het met die veronderstelling dat daar een of ander aanvanklike vlekkelose toestand bestaan het en dat Adam en Eva deur 'n bonatuurlike boosheid beïnvloed is en verdorwe geword het. Die probleem is ' $n$ betrokke liniêre verstaan van tyd as ' $n$ 'onhistoriese daarvoor' en ' $n$ 'historiese daarna'. Die ander probleem is ook dat dit dan geïmpliseer word dat daar 'n ingryping van buite die skepping was wat dit verderf het.

Ek meen dat gebrokenheid nie as 'n aangeplakte laag by die kenbare werklikheid verstaan moet word nie maar dat dit integraal deel is van die werklikheid. Evolusie toon dit ook aan. Erfsonde is dus vir my hierdie integrerende gebrokenheid en soos Paul Tillich dit beskryf het, die mens se vervreemding voor God. Dit kan alleen deur 'n verhouding van genade oorkom word. Dit vra ook eksistensiële moed om te word wat jy reeds in Christus is.

In 1 Korintiërs 8:6 skryf Paulus, 'Vir ons is daar net een Here, Jesus Christus.' Alle uitsprake wat ek dus maak, maak ek binne hierdie betrokke netwerk van verhoudings en ek kyk en beantwoord alles vanuit my subjektiewe wêreld. Dus is daar vir my geen alternatief na God as Jesus Christus moontlik nie. Daarom moet die sola gratia, sola Scriptura, sola fidei in solus Christus oplos. Ek meen ons moet onsself daarvan weerhou om ewigheidsaansprake oor ander mense te maak en ander mense tot die ewige verderf te verklaar.

Ek het myself binne 'n bepaalde teologiese tradisie geplaas, maar dit impliseer nie dat daardie mense wat nie in Christus 
glo, summier afgeskryf mag word nie. Die rykdom en sin van Jesus moet ek met ander deel. Juis dan kan ek getuig dat dit die moeite werd is om te probeer om Jesus se inklusiewe liefde in my lewe te laat gestalte kry.

Vir die gelowige is 'waarheid' ' $n$ Persoon. Openbaring is ' $n$ ontmoetingsgebeure tussen God en mens en in aansluiting by wat ek elders hier vermeld het, is dit nie iets wat óor God of van God geopenbaar word nie, maar alleen God wat God self openbaar.

Die mens is in ' $n$ sosiolinguistiese nis ingebed wat jou werklikheidsverstaan beïnvloed. Dit beteken dat betekenis binne netwerke en verhoudings gegenereer word. In hierdie opsig is die Skrif die vaslegging van die getuienis van God se in-relasie-wees met en in die geskiedenis. Die Skrif interpreteer menslike ervaring en dit is die maatstaf waarop 'n bepaalde geloofsgemeenskap ooreengekom het.

Myns insiens is die uitdaging vir teologie om 'n verstaan van die Skrif te probeer aanbied wat die verhouding tussen openbaring, gemeenskap, teks en gelowiges se ontvangs daarvan profileer. Die kerk kan nie deur die getuienis onaangeraak wees nie. Die evangeliese boodskap verras, daag uit, en oorweldig en die vanselfsprekende antwoorde is nogal vele kere onevangeliese antwoorde. Binne die nis waarin ek my bevind, erken en herken ek die normatiewe aard van die Bybel - dáár, in die Skrif, hoor ek die goeie nuus van Christus se allesomvattende oorwinning en die opstanding van die skepping en die ewige lewe.

Ek beskou dus die skepping nie net in die lig van die ewigheid nie (sub specie aeternitatis), maar ook in die lig van die heelal (sub specie universi). Dit is my uitgangspunt dat die teologie die insigte van die natuurwetenskap op die vraag van die eskatologie moet verreken. Baie fisici meen dat die uiteinde van alles waarskynlik nie anders gaan wees as toe tyd 'begin' het nie. Dit is dus noodsaaklik dat die teologie en wetenskap met mekaar gesprek voer omdat elkeen insigte oor dieselfde kwessie het - ons almal ken immers net ten dele. Die vraag na die uiteinde van alles is vir my die regte verstaan van die verhouding tussen tyd en ewigheid. Die begrensdheid van alle bestaan word deurbreek en daar is hoop vir die wêreld.

In beklemtoning van die kontoere van my teologie, glo ek dus dat die toekomende wêreld nie die einde van tyd en ruimte is nie, maar die voltooiing daarvan is. God versoen nie net met individue nie, maar met die ganse skepping en kosmos. Dit gebeur nie net eendag nie, maar ook nou.

\section{Erkenning}

'n Woord van dank aan Johan Buitendag vir sy toestemming vir die gebruik van ekserpte van die outobiografiese afdeling en die interpretasie van sy teologie.

\section{Mededingende belange}

Die outeurs verklaar hiermee dat hulle geen finansiële of persoonlike verbintenis het met enige party wat hulle voordelig of nadelig in die skryf van hierdie artikel kon beïnvloed nie.

\section{Outeursbydrae}

A.G.v.A. (Universiteit van Pretoria) is die hoofouteur van hierdie artikel. T.v.W. (Universiteit van Pretoria) het die navorsing vir hierdie artikel gedoen.

\section{Literatuurverwysings}

Altner, G., 1977, 'Die Trennung der Liebenden: Variationen über den Ursprung des Lebens', Evangelische Theologie 37, 69-83. http://dx.doi.org/10.14315/evth1977-jg07

Altner, G., 1980, Leidenschaft für das Ganze: Zwischen Weltflucht und Machbarkeitswahn, Kreuz, Stuttgart.

Berkhof, H., 1977, The doctrine of the Holy Spirit, John Knox, Atlanta, GA.

Bokedal, T., 2014, The formation and significance of the Christian biblical canon: A study in text, ritual and interpretation, T\&T Clark, London.

Brümmer, V., 2005, Ultiem geluk: Een nieuwe kijk op Jezus, de verzoening en de Drieeenheid, Uitgeverij Kok, Kampen.

Buitendag, J., 1985, 'Skepping en ekologie: 'n Sistematiese ondersoek na die teologiese verstaan van die werklikheid', DD proefskrif, Department Dogmatiek en Christelike Etiek, Fakulteit Teologie (Afdeling A), Universiteit van Pretoria.

Buitendag, J., 1986, 'Die skepping as gelykenis: 'n Beoordeling van die skeppingsleer van Karl Barth in die lig van die appèl van die ekologiese krisis', HTS Teologiese Studies/Theological Studies 42(4), 674-695. http://dx.doi.org/10.4102/hts. v42i4.2203

Buitendag, J., 1988, 'En nou bly Skepper, skepsel, skepping - hierdie drie: 'n Teologiese profiel in die ekologiese debat', HTS Teologiese Studies/Theological Studies 44(2), 295-313. http://dx.doi.org/10.4102/hts.v44i2.2205

Buitendag J., 1990, 'Die paradigmas van "Kerk en wêreld 2000"', HTS Teologiese Studies/Theological Studies 46(4), 690-707. http://dx.doi.org/10.4102/hts. v46i4.2363

Buitendag, J., 2000, 'nagmaal aan gelowiges - Ouderdom maak nie saak nie. En alkohol?', Skrif en Kerk 21(1), 19-32.

Buitendag, J., 2001, “'Saam een liggaam” (1 Kor 10:17) - Deelname van kinders aan die nagmaal', HTS Teologiese Studies/Theological Studies 57 (1/2), 531-562. http://dx.doi.org/10.4102/hts.v57i1/2.1879

Buitendag, J., 2002a, 'Die dans van die Christen: Die genealogie van tyd en ruimte in 'n postmoderne samelewing', HTS Teologiese Studies/Theological Studies 58(3), 940-955. http://dx.doi.org/10.4102/hts.v58i3.586

Buitendag, J., 2002b, 'Karl Heim se verstaan van ruimte in die debat tussen die teologie en natuurwetenskap', Verbum et Ecclesia 23(2), 291-304. http://dx.doi. org/10.4102/ve.v23i2.1196

Buitendag, J., 2002c, 'Postliberale teologie as teologiese raamwerk vir die kerk se korporatiewe identiteit', HTS Teologiese Studies/Theological Studies 58(1), 1-32. http://dx.doi.org/10.4102/hts.v58i1.551

Buitendag, J., 2003a, 'Die kerk se korporatiewe identiteit', HTS Teologiese Studies/ Theological Studies 59(2), 353-365. http://dx.doi.org/10.4102/hts.v59i2.664

Buitendag, J., 2003b, 'Karl Heim se verstaan van tyd in die debat tussen teologie en natuurwetenskap', Verbum et Ecclesia 24(1), 15-28. http://dx.doi.org/10.4102/ ve.v24i1.308

Buitendag, J., 2003c, 'Die wêreld as gelykenis: 'n Trajek om die middelterm van die "teologie" te vind, HTS Teologiese Studies/Theological Studies 59(4), 1063-1080. http://dx.doi.org/10.4102/hts.v59i4.686

Buitendag, J., 2004a, 'Anders dink anders doen. Op soek na 'n eko-teologiese perspektief op kloning', Verbum et Ecclesia 25(2), 402-422. http://dx.doi. org/10.4102/ve.v25i2.277

Buitendag, J., 2004b, “"Genes Я us" - Of juis nie? Oor determinisme en voluntarisme by die mens met verwysing na homoseksualiteit', HTS Teologiese Studies/ Theological Studies 60 (1/2), 61-81. http://dx.doi.org/10.4102/hts.v60i1/2.529

Buitendag, J., 2004c, 'Günter Altner se jukstaponering van die denksisteme van Schweitzer en Darwin as resiproke korreksies', HTS Teologiese Studies/Theological Studies 60(3), 865-881. http://dx.doi.org/10.4102/hts.v60i3.622

Buitendag, J., 2005a, 'The Human Genome Project as a case study in the debate about the relationship between theology and natural science', HTS Teologiese Studies/ Theological Studies 61 (3), 753-769. http://dx.doi.org/10.4102/hts.v61i3.469

Buitendag, J., 2005b, 'Liturgie as fontein van die lewe: 'n Oorsigartikel oor die kosmiese kartering van Gordon W Lathrop se boek, Holy ground: A liturgical cosmology', HTS Teologiese Studies/Theological Studies 61 (1/2), 65-79. http:// cosmology', $\mathrm{d}$.doi.org/10.4102/hts.v61i1/2.435

Buitendag, J., 2006a, 'Coming in from the outside: A crucial event in the history of ecumenism of the Nederduitsch Hervormde Church', HTS Teologiese Studies/ Theological Studies 62(3), 787-817. http://dx.doi.org/10.4102/hts.v62i3.387

Buitendag, J., 2006b, “'Nuwe wyn in nuwe sakke en die behoud an altwee”: 'n Herbedinking van die Hervormde Kerk se identiteit aan die begin van die $21 \mathrm{e}$ eeu in Suid-Afrika', HTS Teologiese Studies/Theological Studies 62(2), 343-362. http:// dx.doi.org/10.4102/hts.v62i2.371

Buitendag, J., 2007, 'Marriage in the theology of Martin Luther - worldly yet sacred: An option between secularism and clericalism', HTS Theological Studies/ Teologiese Studies 63(2), 445-461. http://dx.doi.org/10.4102/hts.v63i2.228

Buitendag, J., 2008a, 'Binne of buite die blokkie?'n Poging om iets oor tyd en ewigheid te sế,' Verbum et Ecclesia 29(2), 320-344. http://dx.doi.org/10.4102/ve.v29i2.18 
Buitendag, J., 2008b, 'Ecclesia reformata semper reformanda - die ongemaklike eis', HTS Teologiese Studies/Theological Studies 64(1), 123-138, http://dx.doi. eis', HTS Teologiese Studie
org/10.4102/hts.v64i1.7

Buitendag, J., 2008c, '“God met ons": Gelowig nagedink oor die Skrif', HTS Teologiese Studies/Theological Studies 64(3), 1131-1154. http://dx.doi.org/10.4102/hts. v64i3.67

Buitendag, J., 2009a, “'Descendit ad [in] inferna”: A matter of no small moment in bringing about redemption', HTS Teologiese Studies/Theological Studies 65(1) 386-393. http://dx.doi.org/10.4102/hts.v65i1.27

Buitendag, J., 2009b, 'Nature as creation from an eco-hermeneutical perspective: From a "natural theology" to a "theology of nature", HTS Teologiese Studies/ Theological Studies 65(1), 509-518. http://dx.doi.org/10.4102/hts.v65i1.272

Buitendag, J., 2009c, 'Triniteit en triangulasie - op soek na 'n kosmiese liturgie', in G.F. Immink, \& C. Vos (red.), God in 'n kantelende wêreld, bl. 220-230, Protea Boekhuis, Pretoria.

Buitendag, J., 2011a, 'Die beeld van God in die mens vanuit ' $n$ sistematies-teologiese perspektief', Memorandum ingedien ter inligting van die Buitengewone Algemene Kerkvergadering van die NHKA, Oktober 2011, Kerkargief, Pretoria.

Buitendag, J., 2011b, “Epistemology models ontology" - In gesprek met John Polkinghorne', HTS Teologiese Studies/Theological Studies 67 (1), Art. \#897, pages. http://dx.doi.org/10.4102/hts.v.67i1.897

Buitendag, J., 2012a, 'Is die ortodoksie se verstaan van die sondeval belemmerend vir die gesprek tussen teologie en natuurwetenskap', In die Skriflig/In Luce Verbi 46(1), Art. \#41, 10 pages. http://dx.doi.org/10.4102/ids.v46i1.41

Buitendag, J., 2012b, 'Johan Buitendag in gesprek met Fritz Gaum', in G. Claassens \& F. Gaum F. (reds.), God? Gesprekke oor die oorsprong en uiteinde van alles, bl. 328-347, Tafelberg Uitgewers, Kaapstad.

Buitendag, J., 2012c, 'Die noodsaaklikheid van habitat in ons definisie van menswees: Op soek na'n eko-teologiese verstaan van menslike lewe', HTS Teologiese Studies/ Theological Studies 68(1), Art. \#1238, 8 pages. http://dx.doi.org/10.4102/hts. v68i1.1283

Buitendag, J., 2013, 'Gaan na die mier, kyk na sy weë en word wys: Metafoor of pardigma?', HTS Teologiese Studies/Theological Studies 69 (1), Art.\#1976, 9 pages. http://dx.doi.org/10.4102/hts.vi169.1976

Buitendag, J., 2014, 'Panenteïsme as 'n funksionele, induktiewe konstruk in die gesprek tussen die teologie en die (natuur)wetenskap', Verbum et Ecclesia 35(2), Art. \#879, 11 pages. http://dx.doi.org/10.4102/ve.v35i2.879

Claassens, G. \& Gaum, F., 2012, God? Gesprekke oor die oorsprong en uiteinde van alles, Tafelberg Uitgewers, Kaapstad.

Clayton, P., 2004, 'Panentheism in metaphysical and scientific perspective', in P. Clayton \& A. Peacocke (eds.), In whom we live and move and have our being, pp. 73-91, William B. Eerdmans, Grand Rapids, MI.

Cronje G.J. de L, Hugo, W.M.J, Neuland E.W. \& Van Reenen, M.J. (reds.), 1991, Inleiding tot die bestuurswese, 2 de uitg., Southern, Halfway House.

Darwin, C., [1859] 1884, The origin of species by means of natural selection, 6th edn., Johan Murray, London.

De Gruchy, J.W., 1988, 'Racism, reconciliation, and resistance', in C.Villa-Vicencio (ed.), On reading Karl Barth in South Africa, pp. 141-143, Collins Liturgical, London.

Deleuze, G. \& Guattari, F., [1980] 1987, A thousand plateaus, transl. B. Massumi, University of Minnesota Press, Minneapolis, MN

Dibeela, P., Lenka-Bula, P. \& Vellem, V. (eds.), 2014, Prophet from the South: Essays in honour of Allan Aubrey Boesak, Sun Media, Stellenbosch. (UCCSA Publications).

Dreyer, Y., (in druk), 'Community resilience and spirituality - keys to hope for postapartheid South Africa', paper read at a conference of the New Directions in Practical Theology group hosted 07-09 May 2014 by the Princeton Theological Seminary, Princeton, NJ. (to be pubslihed in Pastoral Theology).

Genette, G., [1972] 1980, Narrative discourse: An essay in method, transl. J.E. Lewin Cornell University Press, Ithaca, NY.
Geyser, L., 2014, 'Huldeblyk', in Polssslag (Gemeenteblad van die Nederduitsch Hervormde Kerk Pretoria-Oos), uitg. 13, p. 42.

Grondin, J., [1991] 1994, Introduction to philosophical hermeneutics, transl. J. Weinsheimer, Yale University Press, New Haven, CT.

Heidegger, M., [1962] 2008, Being and time, transl. T. Carman, 7th edn., Sein und Zeit, HarperCollins, New York, NY.

Heim, K., 1949, Der christliche Gottesglaube und die Naturwissenschaft. Der evangelische Glaube und das Denken der Gegenwart, Bd. 4, Furche, Berlin.

Kasper, W., 1977, Jesus the Christ, Burns \& Oats, London.

Kuhn, T., 1962, The structure of scientific revolutions, University of Chicago Press, Chicago, IL.

Lathrop, G.W., 2003, Holy ground: A liturgical cosmology, Fortress Press, Minneapolis, IL.

Lämmert, E., [1955] 1972, Bauformen des Erzählens, 5. Aufl., Metzlersche Verlagsbuchhandlung, Stuttgart.

McGrath, A.E., 2001, A scientific theology, vol. 1: Nature, T\&T Clark, Edinburgh.

Marais, E.N., [1934] 2007, Die siel van die mier, S.F. Honing, J.C. Kannemeyer, A. Klopper, L. Louw \& M. Oosthuizen (reds.), Protea Boekhuis, Pretoria

Moltmann, J., 1977, Zukunft der Schöpfung: Ökologische Schöpfungslehre, Kaiser Verlag, München.

Murphy, N., 1998, Nonreductive physicalism: Philosophical issues', in W. Brown, N. Murphey \& H.N. Malony (eds.), Whatever happened to the soul, pp. 127-148, Murphey \& H.N. Malony (eds.),
Fortress Press, Minneapolis, MN.

Nederduitsch Hervormde Kerk van Afrika (NHKA), 1985, Kerk en wêreld 2000, Kerkargief, Pretoria.

Nederduitsch Hervormde Kerk van Afrika (NHKA), 2014, 'Shared World Communion of Reformed Churches (WCRC)'s status', Facebook communication, viewed 06 September 2014, from https://m.facebook.com/story.php?story_fbid=84581390 5451907\&id=110231152343523)

Pestalozzi, B.C., 2002, 'Looking at the dying patient: The Ferdinand Hodler paintings of Valentine Godé-Darel', Journal of Clinical Oncology, viewed 07 August 2014, from http://jco.ascopubs.org/content/20/7/1948.full

Polkinghorne, J., 2005, Quarks, chaos \& Christianity, The Crossroad Publishing Company, New York, NY.

Schloßberger, M., 2005, Die Erfahrung des Anderen: Gefühle im menschlichen Miteinander, Oldenbourg Akademieverlag, Berlin. http://dx.doi. org/10.1524/9783050047171

Schweitzer, A., [1966] 2000, Reverence for life, M. Meyer \& K. Bergel (eds.), Syracuse University Press, New York, NY.

Thielen, J., 1999, Wilhelm Dilthey und die Entwicklung des geschichtlichen Denkens in Deutschland im ausgehenden 19. Jahrhundert, Königshausen \& Neumann, Würzburg.

Van Aarde, A.G., 2011, 'Memorandum', in NHKA 2011, Agenda vir die buitengewone sitting van die Algemene Kerkvergadering, 04-05 Oktober 2011, Bylae F1, bl. 43 166-176, NHKA, Pretoria.

Van Aarde, A.G. \& Dreyer, T.F.J., 2011, 'Die pendule subjektiwiteit-objektiwiteit in die teologie van Theuns Dreyer - 'n dialoog', HTS Teologiese Studies/Theological die teologie van Theuns Dreyer - 'n dialoog', HTS Teologiese Studies/Theological
Studies 67(3), Art. \#1172, 11 pages. http://dx.doi.org/10.4102/hts.v67i3.1172

Van Wyk, T., 2014, 'Nasie, volk, religie en die kerk as ellips van versoenende verskeidenheid', HTS Teologiese Studies/Theological Studies 70(3), Art. \#2671, 10 pages. http://dx.doi.org/10.4102/hts.v70i3.2671

Van Wyk, T., \& Buitendag, J., 2008, 'Die dimensies "eenheid" en "katolisiteit" in die ekklesiologie van die Nederduitsch Hervormde Kerk sedert Ottawa 1982' HTS Teologiese Studies/Theological Studies 64(3), 1447-1473. http://dx.doi. org $/ 10.4102 /$ hts.v64i3.107

Von Harnack, A., 1924, Marcion: das Evangelium vom fremden Gott. Eine Monographie zur Geschichte der Grundlegung der katolischen Kirche, 2. Aufl., Wissenschaftliche Buchgesellschaft, Darmstadt. (Neue Studien zu Marcion). 